\title{
FUNDAMENTAL ISSUES AND PRACTICAL REQUIREMENTS AFFECTING THE PURCHASE AND SALE OF PRODUCING RESOURCE PROPERTIES
}

\author{
MARTIN G. ABBOTT*
}

In this paper the author examines the significant issues that are present in oil and gas property purchases and sales in Alberta and discusses the "nuts and bolts" problems that are characteristic of particular types of transactions with respect to the positions of both vendor and purchaser. The author further points out how some local practices, especially in the areas of indemnities, representations, and warranties, appear to be peculiar to Alberta.

\section{TABLE OF CONTENTS}

I. INTRODUCTION

II. UNDERSTANDING THE CLIENT'S GOAL 87

III. THE FORMATION OF THE CONTRACT 88

A. WHEN IS A DEAL A DEAL? 88

B. METHODS IN PROCEEDING TO CONTRACT FORMATION 89

1. Non-Binding Letters of Intent 89

2. Formal Offers $\quad 89$

3. Bid Invitations 90

IV. CONDITIONS PRECEDENT 91

A. SUBJECTIVE AND OBJECTIVE CONDITIONS PRECEDENT 92

B. CONDITIONS PRECEDENT AND GOOD FAITH 93

C. CONDITIONS PRECEDENT AND BEST EFFORTS 93

$\begin{array}{ll}\text { V. DUE DILIGENCE } & 97\end{array}$

A. THE DEGREE OF INQUIRY 98

B. THE RELATIONSHIP OF DUE DILIGENCE TO

C. WHAT DUE DILIGENCE IS TO BE PERFORMED? 99

1. Title 100

2. Value 101

3. Condition of the Properties 101

4. Future Contractual Obligations and Liabilities 102

5. Legal Status, Enforceability, Regulatory Consents and Compliance with Existing Agreements 103

6. Interception of Revenue and Novation into Agreements 103

7. Availability of Records 103

D. VENDOR'S PRIVATE RECORDS 104

1. Title 104

2. Value 104

3. Condition of the Properties 105

* Partner, Fenerty, Robertson, Fraser \& Hatch, Calgary, Alberta. 
4. Future Contractual Obligations and Liabilities 105

5. Legal Status, Enforceability and Regulatory Consents 105

6. Interception of Revenue and Novation into Agreements 106

E. PUBLIC RECORDS

1. Registrar of Corporations 107

2. Clerk of the Court 107

3. Sheriff's Offices 108

4. Central Registry 109

5. Registrar in Bankruptcy and Official Receiver 109

6. Department of Energy 109

7. Land Titles Office 110

8. Bank of Canada 111

9. Worker's Compensation Board 111

10. Municipal Taxation Authorities 111

11. Environmental Searches 112

12. Energy Resources Conservation Board 112

13. Crown Royalty Searches 113

14. Employment Standards Code 113

VI. THE NATURE AND MEANING OF COMMON REPRESENTATIONS AND WARRANTIES

A. REPRESENTATIONS AND WARRANTIES ABOUT THE VENDOR

1. Due Incorporation, Organization and Subsistence 114

2. Due Authorization 115

3. No Conflict 116

4. Enforceability 117

5. Governmental Approval 118

6. ARTC Eligibility 119

7. Residency 120

B. REPRESENTATIONS AND WARRANTIES ABOUT THE PROPERTY

1. Title Maintenance 121

2. No Default 121

3. No Litigation 122

4. Good Title to Tangibles 123

5. Financial Commitments 123

6. Operations 123

7. Condition of Assets 125

8. Taxes 125

9. Undisclosed Matters 126

10. Deficient Take-or-Pay Contracts 126

11. Gas Balancing 127

12. Production Purchase Contracts 127

$\begin{array}{ll}\text { VII. INDEMNITIES } & 128\end{array}$

A. PROBLEMS WITH BROAD INDEMNITIES 128

B. THE VENDOR'S NEED FOR INDEMNIFICATION 130

C. DIFFERENT APPROACHES TO INDEMNIFICATION 131 
VIII. INTERCEPTING PRODUCTION REVENUE

A. CONSIDERATIONS IN INTERCEPTING PRODUCTION REVENUE

B. PROBLEMS IN OBTAINING RECOGNITION BY TCPL

\section{INTRODUCTION}

The purchase and sale of producing oil and gas properties is legally and practically very complex. The legal nature of property which is the subject of the transaction usually comprises several types of real and personal property, including property that cannot be characterized as either real or personal under the current state of our law, and property the legal intricacies of which must be unravelled before a purchase and sale can be consummated. The dramatic changes experienced in the industry in the last ten years, such as marketing deregulation, restructuring of take or pay relationships, volatility of energy commodity prices, and insolvencies, to name a few, have resulted in a proliferation of issues which the oil and gas practitioner is expected to deal with effectively when acting for a purchaser or a vendor. The goal of this paper is to review the more significant fundamental issues that are present in typical producing oil and gas property purchases in Alberta and to discuss further the not so common "nuts and bolts" problems that are peculiar to certain types of transactions. The paper also attempts to point out how some of our common local practices, particularly in the areas of indemnities and certain representations and warranties, seem to be peculiar.

Several substantive legal issues and several non-legal issues are discussed. There is obviously legal research involved in the former but in respect of the latter, the discussion is derived from personal experience and observation of the practice as it is largely carried out in the oil and gas community in Western Canada in general, and in Calgary in particular. Although it would have been much simpler to structure the discussion purely from the point of view of either the purchaser or vendor, every attempt has been made to consider the perspectives of both. Issues not considered are several, including those posed by the Investment Canada Act, ${ }^{1}$ the Competition Act ${ }^{2}$ and the Securities Act, ${ }^{3}$ some of which have been addressed in the oil and gas purchase context by other authors. ${ }^{4}$

\section{UNDERSTANDING THE CLIENT'S GOAL}

It is a conceptual mistake of counsel acting for purchasers and vendors of oil and gas properties to think that the transfer of ownership of the real and personal property involved is the goal of the client. The ultimate goal is a financially driven one, not legal, and is simply the purchaser wanting to begin receiving without delay, and to

I. S.C. 1985, c. 28 (1st Supp.).

2. R.S.C. 1985, c. C-34.

3. S.A. 1981 , c. S-6.1.

4. See E.J. Arnett, "From FIRA to Investment Canada" (1985) 24 Alta. L. Rev. I; L. Hunter \& J. Blakney, "An Overview of the New Competition Law: Issues for the Oil and Gas Industry" (1987) Alta. L. Rev. 59. 
continue receiving without abatement or interruption, the revenue stream that he is expecting the property to generate, and the vendor wanting the purchase consideration when it is due, with acceptable ongoing liabilities. Conveying property is only one of the many legal mechanisms used to achieve a purchaser's or vendor's goal, and comprises but a narrow aspect of the deal itself. It is understandable that counsel acting for purchasers and vendors sometimes lose sight of their client's goal, given the overwhelming number of legal intricacies that must often be addressed and solved, the number of steps that must be carried out and the paper that must be generated in any given transaction. It is natural in such circumstances for counsel to gravitate towards those issues with which he is most familiar, such as substantive legal issues. The substantive legal issues then often take on an unrealistic importance, and muddy the way to the desired result. Other functions, such as prioritizing issues, the creation of mundane documents, performance and consideration of numerous searches, managerial tasks and post-closing actions may be ignored or dealt with ineffectively. Counsel is invariably expected to know and implement all of the legal and non-legal functions required to consummate a transaction and understandably, clients want the transaction to close immediately. It is the lawyer, not the investment banker or host of other consultants or participants, that is responsible for closing the deal in a timely fashion and ensuring the adequate protection of his client.

\section{THE FORMATION OF THE CONTRACT}

\section{A. WHEN IS A DEAL A DEAL?}

Determining and controlling the magic moment of contract formation is still one of the greatest legal and practical difficulties that face the businessman and lawyer. The case of Pennzoil v. Texacos is perhaps the most sobering example of what can result from a failure to control the contracting process and understand when a deal has been struck. The takeover by Texaco Incorporated of Getty Oil Company was one of the largest commercial transactions in history and involved many of the most able and well respected law firms in North America ${ }^{6}$ It illustrates the point that disputes over when contractual obligations arise are not peculiar to unrepresented or unsophisticated parties. Controlling contract formation has historically been problematic, and will continue to be. This is because there are several forces at work in the development of any deal, and the variables are unlimited. The purchaser or vendor may not know that their exchange of correspondence and various writings in the course of negotiations is often sufficient to create a binding agreement of purchase and sale. Both the purchaser and the vendor may have been hesitant to call on their counsel during negotiations for fear that their counsels' over-focus on detail, scrutiny and investigation would result in the stillbirth of the deal. The most desirable position for counsel representing a purchaser or vendor is to become involved at an early stage so that he may have some influence over the nature of, and the point in time when, contractual obligations arise, and wise counsel will not let his scrutiny and investigation unnecessarily affect the formation of contract.

Canada has had its share of contract formation litigation over writings identical in substance to that in the Pennzoil v. Texaco case. The law is no different here from that applied by the jury in that case. In Pennzoil v. Texaco, the initial memorandum

5. See M.G. Yudof \& J.L. Jeffers, "Pennzoil v. Texaco" (1988) 27 Alta. L. Rev. 77.

6. See T. Petzinger Jr., Oil and Honor: The Texaco Pennzoil Wars (New York: Putnam, 1987). 
of agreement was written expressly subject to the execution of a definitive merger document. The use of such a provision is still very common in our business, notwithstanding that the common law shows it to be nothing but a recipé for litigation. The leading Canadian case is Calvan Consolidated Oil \& Gas Co. Ltd. v. Manning ${ }^{7}$ which adopted the rules set out in Von Hatzfeldt-Wildenburg v. Alexander: ${ }^{8}$

It appears to be well settled by the authorities that if the documents or letters relied on as constituting a contract contemplate the execution of a further contract between the parties, it is a question of construction whether the execution of the further contract is a condition or term of the bargain or whether it is a mere expression of the desire of the parties as to the manner in which the transaction already agreed to will in fact go through. In the former case there is no enforceable contract either because the conditon is unfulfilled or because the law does not recognize a contract to enter into a contract. In the latter case there is a binding contract and the reference to the more formal document may be ignored.

This principle really provides no guidance to the draftsman other than to avoid using such language unless an express intention is made elsewhere of whether or not the parties intend to be legally bound. The danger of using a provision "subject to the execution of a formal agreement" or words to similar effect without more is illustrated by the fact that Alberta courts have considered similar facts on several occasions and have sometimes found a contract, and other times have not.9

\section{B. METHODS IN PROCEEDING TO CONTRACT FORMATION}

There are several commonly used methods of achieving a binding agreement. Each has its advantages and disadvantages, and choosing the right one should be a decision driven by a careful consideration of the client's needs. The needs of prospective purchasers and vendors will have varying degrees of conflict. The more divergent their needs, the less likely a contract will result.

The first question counsel must ask themselves is whether a formal purchase and sale agreement is necessary. In small property transactions where due diligence can be accomplished in a few days and there is no competition for the property, simply preparing closing conveyances, with appropriate terms in them, may be the quickest and cleanest method of closing. Where there is an extended period of time anticipated between the striking of the deal and closing, such as where due diligence is expected to be extensive, or arrangements with third parties must first be reached, or there is competition for the properties, a formal purchase and sale agreement is required for the protection of the purchaser and the vendor. This document will contain the appropriate conditions precedent, representations and warranties, and indemnities that are essential in most deals. The following is a discussion of typical methods used to control the route to formal contract.

\section{Non-Binding Letters of Intent}

A common method is to have the purchaser's and vendor's relationship progress in steps, from oral discussions to a non-legally binding, but "morally" binding, letter of intent, and thence to a binding contract. Although a letter of intent may not be

7. (1959), 17 D.L.R. (2d) 1 (S.C.C.).

8. [1912] 1 Ch. 284 at 288, 289; in Calvan Consolidated Oil \& Gas Co. Lid. v. Manning, ibid. at 6,7.

9. Alta-West Group Investments Lid. v. Femco Financial Corporation Ldd. (1984), 34 Alta. L. Rev. (2d) 5 (Q.B.); $M$ \& $M$ Drilling Co. Lid. v. W. A. Stephenson Construction (Western) Limited (1987), 56 Alta. L. Rev. (2d) 142 (C.A.); Automated Land Inventory Systems v. Japex Canada Limited (1979), 30 A.R. 544 (S.C.T.D.); Metropolitan Investments Lid. v. T.T.P. Investments Ltd. (1980), 29 A.R. 129 (M.C.); Leitch (Angus) \& Associates Limited v. Legrand Industries Limited (1983), 65 A.R. 232 (C.A.). 
[VOL. XXIX, NO. 1

legally binding, it is often effective in keeping both the purchaser and vendor disciplined to the point where they proceed in good faith to negotiate a binding contract. This is simply because in the business world, with some exceptions, the non-legal forces of honesty, fair dealing and good faith are often as powerful as contractual obligations. Of course, the great difficulty with non-binding letters of intent is that neither party is legally protected until the formal agreement is executed and the nonlegal forces above-mentioned do not carry much weight with certain types of people. Even amongst persons of the highest integrity who do feel morally bound by letters of intent, the detail required in the formal binding agreement will often reveal significant issues that the parties did not consider at the letter of intent stage and over which there is no meeting of the minds. If insurmountable, the deal is stillborn.

Some vendors view letters of intent as an invitation to them to "shop" their property for a higher price, as was the case in Pennzoil v. Texaco. This particular concern can often be addressed in the letter of intent by creating "no shop" obligations for a term certain. This can be one of the few binding provisions in the letter of intent and at least gives the purchaser some comfort in that the vendor has indicated good faith by taking his properties off the market for the term certain. The vendor, on the other hand, may want confidentiality provisions to protect his property during the letter of intent stage, as well as "earnest money" (refundable to the purchaser with interest if no formal agreement arises), to evidence the good faith of the purchaser and to discourage brokers and frivolous offers. The vendor must be satisfied that the purchaser is financially responsible and can consummate the proposed transaction.

An advantage of non-binding letters of intent, presuming that its disadvantages are dealt with or at least understood and accepted, is where the transaction is either so large or so complicated that a benchmark is required upon which the parties can proceed to negotiate a comprehensive formal agreement. Quite often there are so many facts that are unknown about the transaction, such as tax circumstances, third party rights, debt or equity financing, partner involvement, political considerations and others, that developing the proper structure and creating a formal purchase and sale agreement takes several weeks or longer. During that period of time, it is often easy for the parties to forget the basic fundamentals of the deal, and reference to the terms, albeit non-binding, of a previously executed letter of intent can facilitate the successful negotiation of a formal agreement.

\section{Formal Offers}

Another approach to achieve a formal agreement as soon as possible is for the purchaser to prepare a comprehensive offer to purchase and simply submit it to the vendor. Such offers are usually drawn from precedents which include the "kitchen sink" in terms of representations and warranties, conditions precedent and other terms to protect the purchaser from the unknown and the known. This approach is usually appropriate only in those circumstances where the properties and parties involved do not present complex issues. This generally means a small number of oil and gas properties are involved, the purchaser has a high degree of knowledge of the properties (such as where an operator is buying out the non-operator of jointly owned properties), or the purchaser is willing to risk that there are enough appropriate provisions in the formal offer to protect him from the unknown. Commonly, the offer is "off centre" in favour of the purchaser both in terms of the covenants, representations and warranties that are sought and in terms of the conditions precedent to the consummation of the transaction. The vendor usually reacts predictably with the result that a contract is not formed until after a lengthy and difficult negotiation 
Presenting a more balanced agreement at the beginning seems to keep negotiations on a less adversarial level and usually ends up in the same place, and in far less time, than more extreme versions. Counsel for purchasers and vendors must always be mindful of the needs and concerns of the other side, and be ready to offer solutions to impasses.

Many purchasers prefer the formal offer route to one of proceeding first with a letter of intent. The letter of intent itself may require considerable negotiation, which time might have been more appropriately spent on negotiating the formal sales agreement. As well, many purchasers prefer to proceed into negotiations immediately with their own formal agreement so that they can control the drafting process. The draftsman of the document usually has more intimacy with its meaning than the person who only gets to read it, and the draftsman can more easily control the pace of negotiations where more than one draft is involved. The non-draftsman, on the other hand, must react to the document, often without sufficient time to properly review it, and usually has the uphill task of moving the agreement back to centre in terms of reasonableness. Exercising control of drafting goes hand in hand with controlling the contracting process. Controlling the contracting process is often perceived by many parties to be of paramount importance in any purchase and sale transaction. However, the negotiating strength and position of the parties usually, but not always, overrides any disadvantages arising out of not controlling the drafting. The drafting of the formal agreement is by tradition the jurisdiction of the purchaser, for it is this document which he must use to overcome, or at least minimize the effect of, the common law rule of "caveat emptor". ${ }^{10}$ Many vendors carrying out divestitures, however, perceive drafting control to be a real advantage and seek to control not only the drafting, but all aspects of the sale transaction, including the "atmosphere" in which solicitations are invited.

\section{Bid Invitations}

The most recent of several fashions in the oil and gas industry is that of divestiture. Resource companies, and particularly the larger ones, have determined that most of their revenue stream is derived from a small percentage of their properties. Considerable administrative expense can be saved by divesting the less attractive properties. Various bidding procedures have been adopted so that the selling parties can control as far as possible the purchaser's approach, his perception, the information disclosed, and the total contracting process. The vendor seeks to create uncertainty for the prospective purchaser, and give him the perception, whether based on fact or not, that there is a high level of competition for the properties. Recently we have seen the emergence of auction companies specializing in selling oil and gas properties by auction for those vendors who do not want to carry out the sale process themselves.

Typically, a vendor or his agent sets up a data room and solicits interest from various prospective purchasers and invites bids on predetermined parcels of properties. The right to terminate the process at any time is reserved to the vendor, as is the right to sell to someone who is not the highest bidder, or who is not a bidder at all.

10. See Smith v. Hughes, [1861-73] All E.R. Rep. 632 (Q.B.), where at 635 the Court stated: "The general rule, both of law and equity, in respect to concealment, is that mere silence with regard to a material fact, which there is no legal obligation to divulge, will not avoid a contract, although it operates as an injury to the party from whom it is concealed." 
The vendor seeks to eliminate uncontrolled communications to prevent staff from making unnecessary representations to prospective purchasers upon which reliance might be placed. The bids once made are usually deemed to be irrevocable offers for as long as one month, and deadlines for making offers are stated to be strict. Substantial deposits are normally required with the bid. Usually a form of sale document accompanies the bid package, the covering letter to which includes a statement to the effect that variations from the proposed agreement will disqualify the bidder. Other approaches may simply state that a vendor will receive comments on the proposed agreement but will prefer arrangements where there are minimum ongoing liabilities. Further, the purchaser is expected to do all of his due diligence before he makes his offer pursuant to the dictated purchase agreement.

Such procedures obviously present a number of concerns for the purchaser. He may not wish to risk the expense and time required for satisfactory due diligence without at least having the comfort that the vendor has a bona fide intention of selling to him, or anyone. The prospective purchaser might simply be providing the vendor with a free evaluation of the tendered properties. Further, the purchaser has to decide before due diligence is initiated whether the proposed sale agreement will require changes even before due diligence is commenced, and whether changes can be made as later necessitated by the findings of due diligence. It is common for the vendor to draft a sale agreement which provides minimal representations and warranties and ongoing indemnities, with the result that the purchaser has no choice but to include in his bid those representations and warranties and other terms that he feels are essential for his protection. Counsel to a prospective purchaser must alert the purchaser to the deliberate uncertainty that the vendor is attempting to create and urge his client to be disciplined in his approach.

It seems to be invariably the case that if a purchaser's bid is made at a price which the vendor is prepared to accept, the vendor will not reject the bid simply because the purchaser wants some additional protections in the purchase and sale agreement or elsewhere. The parties then proceed to resolve the final form of the purchase and sale agreement. Since the purchaser may have done all of its due diligence, or most of it, by that time, he may not need all of the protections he would otherwise require, with the result that an agreement can be settled quickly. This is clearly not the case if the purchaser does not perform all of its due diligence prior to contracting, which is the normal circumstance in most deals.

\section{CONDITIONS PRECEDENT}

The purchaser is usually at an information disadvantage when buying property. Since our law is still largely one of "caveat emptor", it falls to the purchaser to fully inform himself before he buys the property. He may know so little about the property that the chances are high of discovering something unacceptable in the course of due diligence. It is this risk of the unknown against which the purchaser's counsel must protect his client. This usually results in a purchase agreement that seeks by freedom of contract to undo the harshness of caveat emptor. One of the contracting techniques used to accomplish this is to provide for conditions precedent which have the intended legal effect of discharging the purchaser from his obligation to purchase if any one of the conditions precedent is not fulfilled or waived prior to closing. The vendor, on the other hand, needs as much assurance as possible that the transaction will close and that the purchaser is effectively constrained from killing the deal for unacceptable reasons. 


\section{A. SUBJECTIVE AND OBJECTIVE CONDITIONS PRECEDENT}

Typical conditions precedent used in purchase and sale agreements of producing oil and gas properties can be characterized as either subjective or objective in nature. This is best illustrated by the following examples:

The obligation of Purchaser to consummate the transactions contemplated herein shall be subject to the following express conditions precedent which conditions precedent are for the benefit of Purchaser and may be waived by Purchaser in the manner herein provided for waiver:

1. any pre-emptive or other rights of third parties to acquire any of the Sold Assets or to consent to the transactions hereunder shall have been waived by the holders thereof or all time periods within which such rights may be exercised shall have expired; and

2. Purchaser shall have received from its counsel, in form and substance satisfactory to Purchaser, a favourable opinion that Vendor has good and marketable title to the Sold Assets, unencumbered except for disclosed encumbrances.

It can be seen that the test of fulfilment of the condition precedent in item 1 above is an objective one in that fulfilment is determined by an objective standard and is not subject to the purchaser's or vendor's judgment. Such conditions precedent are not prone to dispute. Item 2 is a classic example of a subjective condition precedent where one party decides alone whether or not the condition has been satisfied. The question every purchaser or vendor must ponder is how unreasonably such subjective discretion may be exercised. This raises the issue of good faith.

\section{B. CONDITIONS PRECEDENT AND GOOD FAITH}

It is often stated that subjective conditions precedent in favour of the purchaser have the effect of creating a "no cost" option for the purchaser because there is a great deal of discretion in favour of the purchaser to decide whether a condition precedent has been fulfilled. The obvious example is the requirement for a favourable title opinion in form and substance satisfactory to the purchaser. Presumably, the purchaser intends to compare the title opinion to something, such as an engineering evaluation or other document setting out the interest that the purchaser thinks he is buying. Purchasers will usually find varying degrees of title defects and often such defects are legitimate. But except in the most straightforward of cases, it is difficult to quantify the risk that a title defect poses. The vendor must always have the concern that a minor defect in title will permit a purchaser not to close because the condition precedent of a "favourable opinion satisfactory to purchaser" has not been met in the eyes of the purchaser. The purchaser may have other motives for refusing to close, and these may remain a mystery to the vendor. Has the purchaser gotten cold feet because he has financing problems, energy prices are collapsing or a better deal can be found elsewhere? Indeed, the contract may not expressly require the purchaser to state why the conditions precedent have not been met. The vendor may only receive a notice from the purchaser that there has been a failure of certain conditions precedent and the agreement is terminated. In the meantime, the vendor has taken his properties off the market and missed other opportunities while waiting for the purchaser to satisfy himself as to the conditions precedent, to say nothing of the time and expense incurred by vendor in going as far as he has on the deal. This raises the issue of whether the common law imposes some sort of "good faith" control on the purchaser's exercise of discretion. 
The law in the United States appears to be much more developed in the area of good faith performance of a contract than in Canada. "In the American Restatement, the duty of good faith states that every contract imposes upon each party a duty of good faith and fair dealing in its performance and its enforcement. ${ }^{12}$ This provision has apparently been adopted by courts in 32 state jurisdictions. ${ }^{13}$ Canadian common law may not have progressed as far as the American common law in regards to good faith performance of contracts, but there are some very important cases that are relevant to the issue.

The leading Canadian case on the issue of good faith and subjective contractual terms is Canada Egg Products, Limited v. Canadian Doughnut Company Limited. ${ }^{14}$ In this case, the purchaser agreed to purchase from the appellant a quantity of powdered egg yoke and egg albumen. As a condition of the contract, it was agreed that "if the powder [was] not satisfactory and within the above specifications"'is in the opinion of the purchaser, it could be returned to the vendor within a specified time. Subsequent to this agreement being entered into, the vendor asserted that the contract was invalid and unenforceable for uncertainty because, as it was argued, "even if goods supplied under the contract would have complied with all the specifications and would have been free from defect, the [purchaser] could still have rejected them on the ground that they were unsatisfactory". 16

The Court dismissed the suggestion of the contract being unenforceable. In dealing with the subjective condition in the agreement, Estey J. stated the following: ${ }^{17}$

The meaning of the clause is neither indefinite nor vague, nor is the language thereof different in effect from that which has been recognized and enforced by the courts over a long period of time. In Truman v. Ford Motor Co. of Canada Lid. [[1926] 1 D.L.R. 960], the plaintiff undertook to supply sods and place them in a manner satisfactory to the defendant. When the latter became disatisfied with the sods it cancelled the contract and the plaintiff brought an action for breach thereof. The jury found that the defendant, in rejecting the sods, had acted honestly but not reasonably. Upon these findings the learned trial judge directed judgement for the plaintiff and this was reversed in the Court of Appeal on the basis that the defendant, having acted honestly, was acting within his contractual rights.

It would appear, under a contract providing for the delivery of powdered egg, which, if not satisfactory, might be returned, the purchaser is within his contractual rights if he honestly rejects the powder. The fact that others might have been satisfied or that he has acted unreasonably is not material " (emphasis added).

It is difficult to understand from the case exactly what the Court meant by "acting honestly". Presumably, it means that the purchaser was genuinely dissatisfied with the circumstances over which he was given discretion, unreasonable as he may have been, and was not seeking to avoid his bargain for some other reason.

In the case of Gordon Leaseholds Ltd. v. Metzger, ${ }^{18}$ the Ontario High Court considered a circumstance where a purchaser had proposed to purchase shares of a company from a vendor. It was a condition precedent to the obligation to close that "all other matters which in the opinion of the solicitors for the Purchaser are material in

11. See E.P. Belobaba, "Good Faith in Canadian Contract Law" (1985) Spec. Lect. L.S.U.C. 73 at 74 .

12. Restatement (2d) of Contracts, s. 205 (1981).

13. Supra, note 11 at 74 .

14. [1955] S.C.R. 398 [hereinafter Canada Egg].

15. lbid., at 399.

16. Ibid., at 400 .

17. Ibid., at 409.

18. (1967), 1 O.R. 580. 
connection with the transaction herein contemplated, shall be subject to the favourable opinion of such solicitors . . . "Thompson J. cited with approval the case of John Grant \& Sons Ltd. v. Trocadero Building \& Investment Co. Ltd, ${ }^{19}$ where the principle was stated very succinctly:

[T]he purpose of making the opinion of a specified person an ingredient in the existence of the right is ordinarily to make the opinion of that person, and not the opinion of a court, the criterion for determining whether the facts give rise to the right. . . . Hence, when such a right is sought to be established before a court, what the court has to determine is, ordinarily, not whether in its opinion the facts exist which give rise to it, but whether the specified person has formed the opinion that they do . . . .

The foregoing case law must alert vendor's counsel to the prospect that even a minor title defect will entitle a purchaser to legitimately terminate an agreement of purchase and sale where the purchaser has a condition precedent that he must be satisfied with title, notwithstanding the fact that a reasonable purchaser, in the eyes of a court, would have accepted such a minor title defect and proceeded to close.

In the local case of Petro Can Oil \& Gas Corp. Ltd. v. Resource Service Group $L t d$., a lawsuit arose out of a refusal of a purchaser to close due to alleged title defects. ${ }^{20}$ The issue in the case was what documents must be produced in discovery proceedings. The plaintiffs were owners of oil and gas assets and entered into an agreement with the defendant to sell such assets for $\$ 45,000,000$. Prior to closing, the defendant presented the plaintiff with a letter stating that certain conditions precedent were not satisfied and the defendant was therefore refusing to close the transaction. One of the conditions precedent relied upon by the purchasing defendant read as follows:

Purchaser shall have received an opinion in form and substance satisfactory to the purchaser from Macleod Dixon, Barristers and Solicitors, as to the title to the partnership portion, the I.G.P. portion and the Petro Can interest conveyed to the purchaser and as to all matters relating to the completion of the closing and assignments and conveyances pursuant hereto including without limitation, regulatory approval, the reorganization and other relevant matters;

The defendant objected to the production of the Macleod Dixon title opinions on the basis of solicitor-client privilege and relevance. The plaintiffs applied for an order compelling the production of the Macleod Dixon title opinions. The defendant asserted that the title opinions would only be relevant in respect to the reasonableness of the defendant's belief and that such reasonableness was irrelevant in light of the holding in the Canada Egg case, which held that the sole issue is whether or not the defendant acted honestly in exercising its discretion. Mason J. apparently disagreed with the assertion and held that reasonableness was relevant to the issue of honesty:21

The defendant contends that given the subjective nature of this determination, the Macleod Dixon opinions are irrelevant. These opinions, the defendant submits, would only be relevant in respect to the reasonableness of the defendant's belief and not as to whether the belief was honestly held. I agree with the defendant in that the Macleod Dixon opinions are directly relevant in respect to whether the defendant's dissatisfaction was reasonable. However, in my view, the reasonableness of the defendant's dissatisfaction is cogent evidence as to whether that dissatisfaction was arrived at honestly and in good faith. For instance, suppose it were concluded that no reasonable person in the position of the defendant would be dissatisfied with the legal opinions. Although not determinative of the issue, this conclusion would be strong evidence that the defendant's dissatisfaction was not honestly held. Therefore, although the Macleod Dixon opinions are not directly relevant to the determination of whether the defendant acted honestly and in good faith by relying on clause $9.1(v)$ in refusing to close, they are certainly relevant to the reasonableness of the defendant's actions which in turn is directly relevant to the defendant's subjective belief.

19. (1937), 37 S.R. (N.S.W.) 535 at $537,538$.

20. (1988), 90 A.R. 220, (Q.B.).

21. Ibid., at 223. 
It should be noted that Mason J.'s judgment decided only the producibility of title opinions and cannot be regarded as authority for the proposition that reasonableness is required in the exercising of subjective judgment. Reasonableness may be relevant evidence in determining honesty, but is not conclusive of it.

There is a further Alberta case which dealt with the termination of a contract due to the failure to meet a subjective condition precedent. In North End Investments Inc. v. Alsman, ${ }^{22}$ the purchaser and vendor entered into an agreement for the sale of a florist shop. The condition precedent in the contract provided that closing depended upon "review of and satisfaction of the Purchaser" of certain financial records, a lease agreement and other things. All was going smoothly until approximately one week before the closing, when the purchaser expressed dissatisfaction with the financial information supplied to him. The vendor discovered that the purchaser was having difficulty with bank financing. Rowbotham J. held as follows: ${ }^{23}$

The interpretation of cl. 23(b) and the words "satisfactory" and "satisfaction" must be read in context with the entire agreement. Reliance upon them must be made in a bona fide manner, honestly and in good faith. The contract was prepared by the plaintiff contra proferentem and it should not now be permitted to terminate the contract by a literal interpretation [sic] of its own language. There must be a valid legal reason for the termination of the contract, not the personal whim of the plaintiff's owner.

It is clear in this case that the Court was not influenced by the Canada Egg case, and instead appeared to interpret the contract as somehow imposing a reasonability standard on the purchaser. This result seems to be somewhat inconsistent with the express wording considered. If the Court concluded as a fact that the only reason for the purchaser's refusing to close was his inability to obtain financing, then it is submitted that the purchaser did not meet the honesty test set out in the Canada Egg case and the case could have been decided on that basis.

There have been other courts that have been unable to resist the temptation to inject in a contract the requirement for reasonableness where one party has the right to exercise subjective discretion. ${ }^{24}$ However, the weight of case authority sides with the view that reasonableness is not to be implied where the parties clearly have agreed to one party exercising subjective discretion.

The case of Caney v. Leith ${ }^{25}$ in obiter dictum gives a few examples of what might constitute acting dishonestly, such as where the solicitors giving an opinion with which the purchaser must be satisfied are seeking to assist their client in getting out of the contract, or refuse to give the matter upon which they must give an opinion any consideration at all, or the reasons for disapproval are patent and absurd.

The principles set out in the foregoing cases are very instructive when negotiating subjective conditions precedent in oil and gas purchase transactions. Hoping that a court will imply some sort of reasonableness standard on the exercise of subjective discretion is a false hope. It is not enough to prove that the subjective discretion was exercised unreasonably. To prove that a person was not acting "honestly" in exercising this subjective discretion is very difficult, short of receiving an admission by such person. The practical effect is that the party in whose favour a subjective con-

22. (1989), 66 Alta. L.R. (2d) 302 (Q.B.).

23. Ibid., at 304.

24. Braunstein v. Accidental Death Insurance Co. (1861), 121 E.R. 904; Dallman v. King (1837), 132 E.R. 729; Cherin v. Scotsburn Co-Operative Services Ldd. (1987), 77 N.S.R. (2d) 91.

25. [1937] 2 All E.R. 532 at 538 . 
dition precedent exists has a great deal of latitude in proceeding or not proceeding with a deal, and probably does enjoy a circumstance akin to an option.

A purchaser or vendor may not wish to live with the uncertainty that a subjective condition precedent presents. He can protect himself from unreasonable, but honest, exercise of discretion by imposing a reasonableness standard in conditions precedent in favour of the other party. For example, a vendor could require the condition precedent referred to above dealing with title satisfaction, to read as follows:

Purchaser shall have received from its counsel an opinion that Vendor has good and marketable title to the Sold Assets, which a reasonable purchaser would accept and proceed to close this transaction.

Alternatively, the vendor and purchaser may set up title defect thresholds, so that if the value of title defects exceeds a certain amount, the purchaser can kill the deal, or adjust the price. These types of provisions usually require a great deal of negotiation, and because few title defects are translatable directly into value, and the categories of defects unlimited, most such provisions cannot avoid reference to a third person to decide whether there is in fact a defect and what value it represents. As a consequence, their usefulness is restricted to larger transactions with widespread properties.

\section{CONDITIONS PRECEDENT AND BEST EFFORTS}

The foregoing analysis should not be confused with the common law principle that requires a party to a contract to use its best or reasonable efforts to bring about the fulfilment of conditions precedent. For example, the purchaser must always be concerned that the vendor, by his actions, can control whether or not certain conditions precedent are met. The vendor may not wish the transaction to close for his own reasons, and may drag his heels in clearing conditions precedent, such as obtaining necessary consents or waivers of third parties. If the purchaser's recourse is limited to terminating the agreement, then the vendor effectively has an option.

There is an extensive line of case law which has considered circumstances where a number of matters had to be resolved before two parties could close a transaction. The Courts have readily implied an obligation on one of the parties to use its best efforts to fulfill the condition precedent. In the case of Dynamic Transport Ltd. v. O.K. Detailing Ltd. ${ }^{26}$ the Supreme Court of Canada considered a situation where a purchaser had agreed to buy land from a vendor with the condition precedent that subdivision must occur before closing. After finding that the vendor was the proper person to apply for subdivision, Dickson J. stated:27

There are many cases in which provisions of a contract were subject to the condition precedent of an approval or a license being obtained, and one party was by inference in the circumstances held to have undertaken to apply for the approval or license: see Hargreaves Transport Lid. v. Lynch; Brauer \& Co. (Great Britain) Ldd. v. James Clark (Brush Materials) Ltd.; Société d'Avances Commerciales (London) Lid. v. Besse \& Co. (London) Lid.; and Smallman v. Smallman. This type of case is merely a specific instance of the general principle that the court will readily imply a promise on the part of each party to do all that is necessary to secure performance of the contract.

26. [1978] 2 S.C.R. 1072.

27. Ibid., at 1083, 1084. 


\section{He further stated: ${ }^{28}$}

The Vendor is under a duty to act in good faith and to take all reasonable steps to complete the sale. . . . The common intention to transfer a parcel of land in the knowledge that a subdivision is required in order to effect such transfer must be taken to include agreement that the vendor will make a proper application for subdivision and use his best efforts to obtain subdivision [emphasis added].

It should be noted that while the Court found an implied obligation on one party to attend to the fulfilment of conditions precedent, the judgment is inconsistent as to the degree of obligation because it refers to both "best" and "reasonable" efforts. It is submitted that a "best efforts" obligation connotes a much higher duty than to merely "take all reasonable steps" to secure the performance of the contract. The words "best efforts" mean "leave no stone unturned", ${ }^{29}$ which might be an expensive proposition. In light of this uncertainty, it would be wise on the draftsman's part to provide an express term describing the obligations of the parties in respect of the conditions precedent. A typical clause provides that "the parties shall proceed diligently, honestly and in good faith and use all reasonable efforts to fulfill the conditions precedent and shall cooperate with each other in their fulfilment".

\section{DUE DILIGENCE}

A purchaser protects himself from the risks imposed by the common law rule of caveat emptor by obtaining knowledge. There are two basic means by which knowledge is obtained in a purchase transaction. These means are performing due diligence, and obtaining appropriate factual representations and warranties in the purchase and sale agreement. The degree of due diligence to be carried out is usually a decision that is solely at the discretion of the purchaser, having regard to its cost, timeliness and effectiveness. The representations and warranties obtained are a matter of freedom of contract, or in other words, negotiation.

\section{A. THE DEGREE OF INQUIRY}

The degree of inquiry that can be carried out in any given transaction is unlimited. What the purchaser normally seeks to do is to verify the basic assumptions and beliefs that he has about the property being purchased, and about the person from whom he is buying it. Ideally, the purchaser will become as knowledgeable as the vendor about the property before he is obliged to purchase. This is rare because it is not practically possible. Before entering into the purchase agreement, the purchaser must decide the categories of knowledge in which he lacks information. The degree of due diligence, conditions precedent, representations and warranties and indemnities eventually required will be driven largely from the missing knowledge. Purchasing from impecunious parties, a multiplicity of parties, trustees in bankruptcy, receivers, or vendors leaving the jurisdiction without leaving behind assets of value, heightens the degree of due diligence required, because representations and warranties or third party guarantees of such parties may not be obtained or are worthless. Corporate officers must understand that a duty is owed to their shareholders to ensure the business of the corporation is conducted prudently. Failing to conduct appropriate due diligence can be very embarrassing for management.

28. Ibid., at 1084.

29. Sheffield District Railway Company v. Great Central Railway Company (1911), 27 T.L.R. 451. 


\section{B. THE RELATIONSHIP OF DUE DILIGENCE TO REPRESENTATIONS AND WARRANTIES}

Many purchasers are of the belief that the necessity for due diligence is minimized where comprehensive representations and warranties are obtained, as though the exercise of negotiating representations and warranties is mainly one of risk allocation. This is a dangerous belief for several reasons. First, representations and warranties have very little value after closing, in any circumstance. Unless the purchaser has some sort of unusual recourse, such as hold-backs or other forms of security, the most that he can expect from representations and warranties is a cause of action for damages or recission. This makes the purchaser a contingent unsecured creditor who, if he succeeds in getting a judgment, will stand behind creditors with secured or higher claims or persons with statutory priority. The vendors who readily give representations and warranties carelessly, or in full knowledge that they are false, are invariably the same ones who are impecunious, or will be out of the business and jurisdiction immediately after closing. Further, many vendors do not know their own properties and circumstances as well as one might expect. Sometimes there are legitimate reasons for this, such as where the vendor is a passive investor and does not operate the properties, or just bought them himself. Sometimes there are no legitimate reasons for this, such as where the vendor runs a sloppy business, with corresponding chaotic records and muddled minds administering them. Even large organizations with the best of management can suffer communication lapses between departments, and an assumed state of facts by the department carrying out the transaction might be completely in error. A representation and warranty that shoud not be given is then given, to the eventual disappointment of the purchaser.

Second, even where the party giving the representations and warranties is financially responsible, many aggrieved purchasers will not pursue a claim even in the most clear-cut of cases. The oil and gas world is a small one and suing another player in the industry is a decision not lightly taken by most companies. This is to say nothing of the often extreme costs of litigation, not only in terms of legal fees, but also in terms of the time investment of senior management which necessarily takes them away from more productive activities. This, coupled with the inherent uncertainties of litigation and the embarrassment factor that public companies in particular must consider, has resulted in very little litigation on representations and warranties when one considers the number of transactions that are carried out in any given year. A disappointed purchaser will always question whether a false representation and warranty could have been verified by due diligence. Indeed, a problem discovered before closing bears no relationship in significance to the same problem discovered after closing.

Third, viewing representations and warranties as a risk allocation mechanism can backfire. A representation and warranty will not give rise to a cause of action unless true reliance is placed upon it. ${ }^{30}$ There are several ways in which a court vitiates reliance. If a purchaser in his due diligence discovers that a representation and warranty is not true and closes anyway, then clearly there is no reliance. If a purchaser independently checks a fact and mistakenly decides solely on the basis of his own checking that the fact is correct, he cannot later allege reliance. ${ }^{31}$ There is no reliance 
if the purchaser did not care whether the representations and warranties were true or not, ${ }^{32}$ such as where a purchaser is so eager for the deal that he would have closed whether or not he knew the state of certain facts. The state of mind of the person alleging reliance is obviously very relevant to the issue of reliance, and any purchaser suing on a breach of representations and warranties must face the risk and uncertainty posed by such a defence. Risk allocation is more appropriately dealt with through the mechanism of indemnities where state of mind and reliance is irrelevant to enforcement. Indemnities are discussed below.

The real value in representations and warranties is their being a useful tool in assisting the purchaser in information gathering prior to closing. This happens in two basic ways. The vendor, if he is prudent and honest, will review his own affairs in light of the representations and warranties requested by the purchaser. The vendor will then normally disclose problems that prevent him from giving troublesome representations and warranties and these can usually be solved or managed. The potential ongoing liability that a representation and warranty represents constitutes the incentive for the vendor to carefully check his own affairs. On the other hand, it must be recognized that many vendors will negotiate to remove representations and warranties entirely, or revise their wording, such that they can be given without the vendor disclosing to the purchaser problems which otherwise would have been disclosed, or problems which the vendor suspects may exist but wants to turn a blind eye. The purchaser must be ever alert to the real reasons why a vendor wants changes or deletions to representations and warranties.

Lastly, and most importantly, most agreements have as a condition precedent the requirement that all representations and warranties given on the date of execution must also be true in all material respects as of the closing, which is usually evidenced by a "bringdown" certificate executed by an officer of the party giving it. This mechanism creates a standard which the vendor knows must be met for the transaction to close. If he truly wants to close, then it is likely that the standard will be met. This is a far more powerful tool in the hands of the purchaser than is a lawsuit after closing based on a breach of a representation and warranty.

\section{WHAT DUE DILIGENCE IS TO BE PERFORMED?}

It is very difficult for a purchaser to know what information he should have without knowing what information is available. Experienced counsel can be of great assistance to a purchaser by advising him that he is naturally making several assumptions about not only the property, but also the vendor. Counsel can then recommend what sources of information outside of the purchase and sale agreement, both public and private, can be accessed to validate these assumptions. The following is a general discussion of the usual assumptions that are present in a purchase and sale transaction of oil and gas properties, and what sources of information outside of the purchase and sale agreement can be used to confirm the assumptions. Several of these assumptions are also covered by representations and warranties and sometime indemnities, and are discussed below. 
It should be remembered that the purchaser's goal is a financially driven one, and that often the purchaser will have carried out no basic due diligence of his own other than coming to a conclusion as to the general identity of the properties, their value, based on the best information that he has available to him at the time, and a general idea of who the owner might be of that property. To the extent the assumptions must be verified before closing, appropriate conditions precedent must be included to permit this verification. The verification process often involves lawyers, accountants, engineers and other professional advisors.

Timeliness of due diligence is important. The earlier problems are identified, the more likely that they can be solved before closing. If they cannot be resolved satisfactorily, then further effort and expense in other areas of the transaction can be avoided.

\section{Title}

A purchaser invariably assumes that the vendor has good title to the property, unencumbered except for those burdens of which the purchaser has knowledge. The vendor may represent several silent partners or at least think that he represents them. Title is normally confirmed by a legal title review which uses several sources of information. The most important source is the vendor's records. There are also several public records offices in Alberta which can be searched for a variety of factual matters which relate to title. These are discussed below. The purchaser may also be assuming that he is getting certain property associated with mineral interests, such as well batteries, gathering systems, gas plants, sales pipelines, gas contracts, seismic data, geological data, surface rights, production inventory, permits, licences and the right to benefits under contracts, which are choses in action. The vendor's and purchaser's discussions may have focused on the mineral aspect of the properties, and there may not be a mutuality of intent on the property package when counsel is called. It is essential at the outset of any transaction to identify in detail the property the vendor or purchaser thinks is involved, and the correct parties. Failure to thoroughly and precisely identify the proper parties and property in the beginning frustrates proper due diligence.

\section{Value}

Prior to making an offer on the properties, the purchaser has come to a conclusion as to the value of the properties, either on his own or by reference to a report prepared by the vendor or a third party, such as an engineering firm. A determination of the value of oil and gas properties is most commonly accomplished by calculating the present value of the future net cash flow that one can expect to derive from the properties. This is no more than an estimate of the future net revenue that the property can be expected to produce, before and after income tax, which is then discounted to take into account the time value of money and other risks, to come up with a present value. The calculation is simply comprised of a mathematical formula, all the components of which are assumptions of what will be the case in the future. Some of these assumptions are based on historical fact, and the balance involve a high degree of conjecture. For example, estimates of future production revenue depend on things such as estimates of recoverable reserves in place, future operating and capital costs, future royalties, burdens, taxes and credits, future production rates and, of course, future prices. Many purchasers have found themselves after closing with operating costs 
and required capital expenditures that bear no relationship to the assumptions made prior to closing, and the historical information upon which the purchaser's assumptions were based are discovered to be not entirely accurate.

Every purchaser should determine to what extent he needs his assumptions as to value verified. The purchaser may well want to verify the historical basis for his assumptions as a condition precedent to close. Production history and operating costs are confirmed mainly through the records of the vendor. Forecasts of prices, production taxes, Crown royalties, income taxes, recovery of credits and rebates are usually matters of great conjecture, and are assumptions made usually without a need to review the vendor's records. Exceptions are, of course, wells that are represented as being under a "royalty holiday" or under royalty relief pursuant to enhanced recovery schemes. These circumstances can be verified by reference to the drilling dates, the relevant legislation or governmental royalty relief orders. ${ }^{33}$ Also, future production rates, at least for natural gas dedicated to one gas buyer, are largely determined by contractual provisions affecting that relationship and in many circumstances, the marketing success of that gas buyer. Production penalties imposed by agreement may also exist. The purchaser's determination of value may assume that the purchaser will access tax pools of the vendor if all or substantially all of the property of the vendor is being purchased. A review of the vendor's income tax returns and financial statements may be essential to assess tax pool status and accessibility, particularly if representations and warranties are of doubtful value.

\section{Condition of the Properties}

The purchaser assumes that the properties he is buying are in a certain condition, usually good and operable. An on site inspection can reveal a great deal about a property and counsel for a purchaser should strongly recommend this to his client whenever aboveground assets can be inspected. A review of the vendor's engineering records may disclose some serious technical problems with equipment, downhole conditions and breaches of laws, such as environmental laws. Reviewing the vendor's records and searching the relevant government agencies can determine the existence of appropriate licensing and breaches of laws governing operations of facilities which are being enforced. These specific searches are discussed below.

\section{Future Contractual Obligations and Liabilities}

The purchaser usually assumes that future contractual obligations affecting the properties and for which the purchaser will be responsible are only those that one would encounter in the normal course of operating producing properties. The purchaser may not know that there are drilling commitments, workover commitments, facility construction commitments, enhanced recovery scheme commitments, or a host of other financial commitments that arise out of the operating agreement into which the purchaser will be novated, or other agreements into which the vendor expects to novate the purchaser. There indeed may be operator's liens, defaults or failures to comply with laws in general, and unusual contractual relationships, such as future take or pay gas recoveries or gas balancing schemes. Disgruntled joint

33. Issued pursuant to the Mines and Minerals Act, Petroleum Royalty Regulations, Alta. Reg. 93/74, s. 4.03. 
owners of the vendor may be carrying out audits of his operatorship. The purchaser may not know that if he is buying all or substantially all of the vendor's assets that he may trigger provisions of certain super priority statutes (discussed below). Gathering information on these types of obligations and liabilities outside of representations and warranties is usually available only from the vendor's records and other joint owners of the properties, if they are co-operative.

\section{Legal Status, Enforceability, Regulatory Consents and Compliance with Existing Agreements}

The purchaser assumes that the vendor has a legal status which permits him to enter into and perform the agreement of purchase and sale, to do business as he is conducting it, to have done all that is necessary internally, such as shareholder's or director's resolutions, to enable him to carry out the purchase and sale, that the purchase and sale will not violate or conflict with laws or agreements binding the vendor or his property, that no governmental authorization is required to sell the property and that the purchase and sale agreement is enforceable against the vendor. None of these assumptions can be taken for granted. The purchaser assumes that he is not prohibited from buying due to laws such as the Investment Canada Act, ${ }^{34}$ and the Competition Act, ${ }^{35}$ and that the vendor has Canadian residency under the Income Tax Act. ${ }^{36}$ Inquiries into the business and corporate background of the vendor and purchaser usually disclose whether these are issues or not. Residency pursuant to the Income Tax Act can usually be determined by corporate searches and comparison thereof to provisions of the Income Tax Act. Investment Canada issues are quite often dealt with solely through representations and warranties, unless the purchaser should have knowledge to the contrary. Several of the foregoing assumptions can be buttressed by representations and warranties and public searches, which are discussed below. Violation or conflict with agreements can be determined to some extent by reviewing the vendor's agreements.

\section{Interception of Revenue and Novation into Agreements}

The purchaser assumes that he will be able to intercept revenue immediately upon closing, that he will become novated into all relevant agreements and that he will be able to enforce rights under those agreements within a short period of time after closing. These assumptions are so significant that they are dealt with separately in this paper. The purchaser may also be assuming that he will enjoy operatorship after closing although most operating agreements contain provisions to preclude a transfer of operatorship.

\section{Availability of Records}

The purchaser assumes that the vendor has records pertaining to due diligence that can be made available to the purchaser. The vendor may have few or no records at all, particularly if he is not the operator of the property or is a non-industry person or

34. Supra, note 1.

35. Supra, note 2.

36. R.S.C. 1952 , c. 148. 
passive investor whose property is held in trust by a party recognized in the various title and operating agreements. The purchaser may wish to ensure that the vendor can get access to relevant records for the purchaser, from the operator or otherwise.

\section{VENDOR'S PRIVATE RECORDS}

Once the purchaser has identified the assumptions that he has made and what ones he wishes to verify, it can be determined which of the vendor's records are necessary to be reviewed. Provision can then be made in the purchase and sale agreement to ensure that the purchaser has access to these records. Consideration can be given to imposing a best or reasonable efforts obligation on the vendor where the relevant records are in the possession of third parties, such as trustees or operators. The following are typical documents that can be reviewed to address the assumptions of the purchaser. These documents are not exclusive to any one assumption and can provide information on several of the assumptions. It should always be remembered that some of the most interesting information is derived from the correspondence concerning any particular asset, as this is where disputes, defaults, threats and demands are normally documented.

\section{Title}

The ideal vendor will have records completing a chain of title from the granting of the mineral lease through to the acquisition of any interest by the vendor, and any dispositions or alienations by him. This will include the vendor's own interpretation of what he owns, which is usually contained in lease or land summaries, plus leases, unit agreements, trust declarations, operating agreements, royalty agreements, net profits interest agreements and the like, participation agreements, farm-in and farmout agreements, sale and purchase agreements, previous title opinions, pooling agreements, assignments, loan agreements, documents pertaining to the granting of security, including assignments under section 177 of the Bank $A c t,{ }^{37}$ fixed and floating charge debentures, mortgages, deeds of trust, chattel mortgages, general assignments of book debts, specific assignments of contracts and debts, evidence with respect to the payment of rentals, delay rentals, shut in royalties and other payments due under leases, maps and land plats, all purchase, sale, processing transportation and pipeline agreements, and production records. The vendor might also be asked to produce a list of pending and threatened litigation which might affect title.

\section{Value}

The purpose of obtaining documents relating to value is to confirm the purchaser's assumptions in arriving at his opinion of value. Part of that process is done by virtue of the title review, which confirms the nature and magnitude of the interests that the vendor has in the properties, and the burdens to which they are subject. The purchaser may also wish to review records which will provide evidence of such things as recoverable reserves, operating and capital costs, production rates, royalty holidays, royalty relief schemes, marketing circumstances and a reconciliation of revenue checks and operating and capital costs to working interests. This entails a review of engi- 
neering well files, production records and production accounting records, spud dates of wells, transportation agreements (including a determination of whether transportation is on a firm or interruptible basis), income tax returns for Alberta Royalty Tax Credit ("ARTC") eligibility ${ }^{38}$ and tax pool status, production penalty information and production marketing information.

\section{Condition of the Properties}

In addition to the records described above, the purchaser may want to review the minutes of meetings of any operating committee of common facilities or properties, equipment leases, government licenses and permits, equipment warranties, utilities agreements, inventory statements, schedules of equipment, maintenance records of significant equipment, field contracts and related agreements pertaining to the operation of facilities, equipment service agreements and equipment purchase agreements.

\section{Future Contractual Obligations and Liabilities}

Operating agreements usually state what amounts an operator can expend without written authorization of joint owners; customarily, authorizations for expenditure are required for anything above those limits. In addition to those records and the ones discussed above, the following records can be reviewed: property tax returns, sales tax returns, results of joint owner audit inquiries, status of take or pay gas commitments and recoveries, demand charge obligations under transportation agreements, current budget and forecast information for joint facilities, independent operations notices, contract operator agreements, easements, surface leases and rights of way agreements.

\section{Legal Status, Enforceability and Regulatory Consents}

Before a purchaser should request records of the vendor to determine such things as legal status and internal corporate requirements, he must determine whether he is better off relying on representations and warranties and certain statutory provisions, or legal opinions as to enforceability. These are discussed below. It is not typical for an asset purchaser to inquire to any great degree into the internal corporate affairs of the vendor, with the exception of occasionally requiring resolutions of the directors and perhaps shareholders of the vendor and certificates of incumbency of signing officers at closing. If the internal affairs of a vendor are to be scrutinized, this usually begins with the vendor's minute book which generally contain articles of incorporation, by-laws, shareholder's resolutions, unanimous shareholder agreements, director's resolutions, minutes of meetings, annual returns, financial statements and share certificates. This will usually give information as to the laws and jurisdiction which created the entity, and facts pertinent to the application of the Investment Canada $A C t^{39}$ and residency under the Income Tax Act. ${ }^{40}$

38. Pursuant to Part 6 of the Alberta Corporate Income Tax Act, R.S.A. 1980, c. A-17.

39. Supra, note 1.

40. Supra, note 36. 


\section{Interception of Revenue and Novation into Agreements}

Contractual arrangements which produce revenue for the vendor must be scrutinized. Some of these have already been mentioned above but include oil sales contracts, gas purchase contracts and all amendments thereto, facility, construction, ownership and operating agreements, land operating agreements, royalty agreements and net profits interest agreements. Since there is no public mechanism presently existing to register assignments of proceeds under production contracts, the purchaser must review all assignments and security granted by the vendor. The effect of new legislation on the matter is discussed below. ${ }^{41} \mathrm{~A}$ review of operating agreements and an identification of the other parties thereto will often provide some indication of problems that can be anticipated in attempting to transfer operatorship.

\section{E. PUBLIC RECORDS}

The basic public due diligence to be performed is that of searches at public registries. These searches are generally performed by either identifying the vendor or the property, or certain other persons connected with them. Those certain other persons may include the operator of a significant property or a person who holds the interest of the vendor, being a silent partner, in trust for him. It is important to note that simply identifying a corporation as the name to be searched is insufficient. Any predecessor corporation, by virtue of name change, amalgamation, liquidation or windup must also be identified and searched unless the event occurred so long ago that it does not reasonably present a risk in the context of the transaction. It should always be kept in mind that there are 12 judicial districts in Alberta, and two freehold land registration districts. Searches are generally not carried out in every judicial district unless significant assets, such as a gas plant, are located in a particular judicial district. This means that there is a risk certain problems will not be discovered, such as law suits and writs of execution filed only in the non-searched judicial districts.

There is always a time delay in conducting searches. It is advisable to carry out searches before the formal agreement is executed, to the extent that it is possible. Fundamental problems might be revealed, such as a vendor who is being petitioned into bankruptcy or who has writs filed against him, which have to be dealt with in the structure of the deal as a whole as opposed to simply killing the deal for failure to meet conditions precedent. Consideration must be given to carrying out all relevant searches immediately prior to closing to determine whether circumstances have changed to the prejudice of the purchaser. Depending on the agency being searched, the period of time to obtain results can be anywhere from a few hours to several days. Purchaser's counsel should ensure that searches are ordered an appropriate period of time before they are needed, and that the purhcaser is aware of the ramifications of a gap in time between the effective date of those searches and when they are received. It must always be remembered that ordering the searches is insufficient; the searches must be reviewed and considered in the context of the transaction. The basic searches that can be carried out are described in the following pages. 


\section{Registrar of Corporations}

Section 259 of the Business Corporations Act" (" $\mathrm{BCA}$ ") provides that any person who pays a prescribed fee is entitled to examine documents required by the BCA to be sent to the Registrar. Those documents include such basic things as articles of incorporation, identification of directors, identification of shareholders for private corporations, extra-provincial registration documents, articles of amalgamation or dissolution, appointments of receivers and debt instruments such as debentures. These documents provide much of the basic information required for due diligence. It is also in this initial search that it can be determined whether the corporation has predecessors by amalgamation or change of name which one should consider searching.

A mortgage register copy is obtainable but is simply a summary of the Registrar of Corporation's interpretation of what mortgages have been registered, and is occasionally in error. Reference to microfiche and the day book maintained by the Registrar in Edmonton is the only means of obtaining an accurate and up-do-date picture of the status of the corporation. Section 17 of the BCA provides that mere registration of a document with the Registrar of Corporations is not constructive notice. This provision is not conclusive of the issue of priority, however, because the common law system of priorities provides that a legal interest taken as a mortgage defeats subsequently taken interests. A certificate of status is also available from the Registrar and is evidence of corporate status. This is an essential component of the ability of a corporate vendor to enter into the purchase and sale agreement and perform it. Corporate status is discussed further below.

The Personal Property Security Act (" "PPSA") will repeal the provisions of the BCA concerning mortgage registrations. ${ }^{44}$ The transitional provisions of the PPSA provide that a registration of a debenture under the $\mathrm{BCA}$ is deemed to be a registration under the PPSA until October $1,1993 . .^{45}$ Searches will have to be conducted under both Acts until that time. It seems unclear where floating charge debentures affecting land are to be registered once the PPSA is in force. Floating charge debenture holders will likely have to proceed with specific land registrations to provide notice of their interest. If they do not, the common law appears to govern ${ }^{46}$ and counsel for purchasers will have to be particularly concerned about their existence and problems with constructive notice.

\section{Clerk of the Court}

The purpose of searching the office of the Clerk of the Court is to determine what sort of litigation is occurring that might affect the vendor or his properties. There are 12 judicial districts in Alberta and searches are normally conducted in judicial districts where it is likely litigation would occur, such as in the judicial districts of Calgary or Edmonton, or in any judicial district where significant assets are located. The search is done by the name of the vendor. Much of the litigation in which oil and gas companies are involved arises out of surface disputes with surface land owners

\footnotetext{
42. S.A. 1981 , c. B-15.

43. Supra, note 41 .

44. Ibid., s. 77.

45. Ibid., s. 75(3).

46. See also ibid., s. 66 .
} 
or field contracts. Those disputes are typically litigated in the judical districts in which the land is situated. It is quite common for insolvent vendors to have forgotten to pay surface rentals and field contractors and therefore a purchaser may want to search in all relevant judicial districts when a vendor is in financial difficulty.

Operators are quite often the only party named as a defendant, so it is customary to search the name of the operator in judicial districts in which a major facility, such as a gas plant, is located, or in a judicial district where the operator is likely to be sued, such as Calgary or Edmonton.

Search results obtained from the Clerk of the Court only indicate actions where the person searched is a party. The subject matter of the dispute can only be determined by obtaining a copy of the pleadings and other documents filed. That in turn will not be helpful in terms of the merits of the complaint. If the results of the legal action can adversely affect the properties being purchased, then obviously the purchaser may have to come to a conclusion as to the merits of the claim.

\section{Sheriffs' Offices}

Sheriffs' Offices are customarily co-located with the Clerk of the Court in each of the 12 judicial districts in Alberta. A sheriff's office can be searched for writs of execution and other registrations, such as those arising under the Worker's Compensation Act. ${ }^{47}$ The search is carried out by name. Writs of execution when registered with the Sheriff bind all the goods of a judgment debtor located in that judicial district. ${ }^{48}$ There is case law supporting the view that a writ of execution not registered at the Land Titles Office pursuant to section 122 of the Land Titles Acts binds lands anyway, which would include leases of Crown mineral rights. ${ }^{50} \mathrm{~A}$ prospective purchaser should not take the risk that a writ of execution not registered at the Land Titles Office does not bind the Crown mineral leases of the vendor. It certainly is the case that the filing of a writ of execution at the relevant Land Titles Office creates an irritant to freehold transactions. ${ }^{51}$ There is no corresponding mechanism under the Mines and Minerals $A$ Ct $^{52}$ to preclude a transfer of a Crown mineral or surface lease as there is under the Land Titles Act.

Counsel for the purchaser should also be alert to the situation where execution debtors convey their Crown mineral leases to a shelf company against whom no writs are registered, which is possible because there is no mechanism to prevent the Minister of Energy from transferring a Crown lease in the face of a writ, thereby putting the shelf company in a position to convey property with the appearance that no writs apply to it. Section 4 of the Seizures $A c t^{53}$ may provide protection to a bona fide purchaser for value without notice, insofar as personal property is concerned, but purchaser's counsel would nevertheless be prudent to search for writs of execution applicable to predecessors in the chain of title if the previous transaction appears to have suspicious purposes.

47. Workers' Compensation Act, S.A. 1981, c. W-16, s. 131.

48. Seizures $A c t$, R.S.A. 1980 , c. S-11, s. 4.

49. R.S.A. 1980 , c. L-5.

50. See C.R.B. Dunlop, Creditor-Debtor Law in Canada, (Toronto: Carswell, 1981) at 172.

51. Supra, note 49, s. 122(2).

52. R.S.A. 1980 , c. M-15.

53. Supra, note 48. 


\section{Central Registry}

The Chattel Security Registries Act $^{54}$ establishes a registration system administered by the Registrar of Personal Property. ${ }^{35}$ Section 8 of that Act entitles a person to make a search against the name of a debtor or certain equipment. The purpose of the Act is to set up a registration system for personal property where different types of security pursuant to various other statutes ${ }^{\text {s6 }}$ of Alberta are registered. Chattel mortgages, general assignments of book debts and debentures are registered pursuant to the Act. The search is done at Central Registry.

The PPSA, which is scheduled to come into force on October 1, 1990, is intended to replace the Chattel Security Registries Act and all or part of the authorizing acts to which it relates. Search procedures under the PPSA are not anticipated to be significantly different from that existing for Central Registry searches. The PPSA transitional provisions will require searches under both the PPSA and at Central Registry be conducted until October, 1993.57

\section{Registrar in Bankruptcy and Official Receiver}

Section 43 of the Bankruptcy $A t^{58}$ provides that a creditor must file a bankruptcy petition against a debtor in the court having jurisdiction in the locality of the debtor. There are two bankruptcy divisions in Alberta, being the Registrar of Bankruptcy connected with the Court of Queen's Bench of Alberta in Bankruptcy in Calgary and Edmonton. Section 49(1) of the Bankruptcy Act provides that an insolvent person may make an assignment of all of his property, which is done pursuant to section 49(3), to the Official Receiver. Similarly, under section 62(1) of the Bankruptcy Act, a proposal in bankruptcy is also filed with the Official Receiver. The Official Receiver can be searched with Consumer and Corporate Affairs, Ottawa, by telephone, followed by a written confirmation. These searches are done by name and are intended to disclose registrations, entries, assignments or proposals in bankruptcy, which obviously can impair the ability of a vendor to enter into and consummate a transaction.

\section{Department of Energy}

A purchaser may search a Crown mineral or surface lease or license by lease number or legal description. A Crown "search letter" provides such information as lease or license number, legal description and zone designations, rights granted (such as natural gas or petroleum and natural gas), registered lessees, dates of issuance and continuation of the Crown lease past the primary term, rental status, registration of builder's liens and security notices. This search is fundamental to title reviews, notwithstanding that the Crown will accept no responsibility for the accuracy of the search letter. Historically, there have been periods where the search letters have not

54. S.A. 1983, c. C-7.1.

55. Ibid., s. 4.

56. The Assignment of Book Debts Act, R.S.A. 1980, c. A-47; Bills of Sale Act, R.S.A. 1980, c. B-5; Conditional Sales Act, R.S.A. 1980, c. C-21; and Business Corporations Act, supra, note 42.

57. Supra, note 45.

58. R.S.C. 1985 , c. B-3. 
been up-to-date with such things as transfers, rentals, lease continuations and deep rights reversions. Section 140(4) of the Mines and Minerals Act ${ }^{59}$ establishes a priority system in respect of transfers and registered security notices. Security notices usually relate to fixed charged security granted under section 177 of the Bank Act, ${ }^{60}$ or pursuant to a trust deed, debenture or other mortgage. Copies of the security notices themselves can be obtained, but these may or may not reveal information about where the grantor of that security derived its interest in the lease or whether the security covers only certain zones. Further inquiry is enabled, to a certain degree, by section 142 of the Mines and Minerals Act, whereby certain persons can serve a demand for further information on the party who has registered a security notice. This mechanism is rarely used because it is so cumbersome.

The Department of Energy can also be searched pursuant to section 19 of the Freehold Mineral Rights Tax Act to determine whether the tax exigible under that Act has been paid. Failure to pay tax under that Act can lead to a cancellation of freehold mineral rights in favour of the Crown. ${ }^{62}$

\section{Land Titles Office}

There are a number of searches which can be conducted at the Land Titles Office in the North or South Land Registration Districts. Section 17 of the Land Titles Act ${ }^{63}$ provides that the Registrar of Land Titles must record the particulars of each instrument or caveat which encumbers a parcel of land on the certificate of title to that land. Searches of the Land Titles Office for relevant title documents are essential to freehold title reviews. These freehold title reviews can take the form of historical title opinions which review the chain of title from the original grant of the mineral rights from the Crown through to the present, or title opinions on the interest of the vendor, which is customarily derived from a freehold lease of mines and minerals. A general registry certificate from the Land Titles Office is obtained to determine whether any writs of execution have been registered against a person which can impair Land Titles transactions pursuant to section 122(2) of the Land Titles Act. Numerous statutes permit filing of claims against certificates of title to land. ${ }^{64} \mathrm{~A}$ search of the certificate of title to freehold mineral rights will also include a search of relevant registrations on the back of the certificate of title. Surface titles are not normally searched unless there is a concern with a vendor in financial extremes. Surface titles will frequently show builder's liens in favour of persons who provided goods and services. Quite often the persons who file liens are contract field operators who are not aware that liens can be filed against mineral estates.

59. Supra, note 52.

60. Supra, note 37.

61. S.A. 1983, c. F-19.1.

62. lbid., s. 14.

63. R.S.A. 1980, c. L-5.

64. See, for example, the Bank Act, supra, note 37, s. 177; Bankruptcy Act, supra, note 58, s. 74; Employment Standards Code, S.A. 1988, c. E-10.2, s. 1 14(2); Workers' Compensation Act, S.A. 1981, c. W-16, s. 127; Freehold Mineral Rights Tax Act, S.A. 1983, c. F-19.1; Builders' Lien Act, R.S.A. 1980, c. B-12; Tax Recovery Act, R.S.A. 1980, c. T-1; and Surface Rights Act, S.A. 1983, c. S-27.1. This list is not exhaustive. 


\title{
8. Bank of Canada
}

The Bank Actos creates security interests which may be registered pursuant to sections 177 and 178 . Section 177 security is registered at the applicable land registry office or with the Department of Energy. Section 178 security is typically granted to wholesalers or retailers of agriculture, mining, forest, or sea products, or persons engaged in manufacturing or farming. It is hence virtually unknown that a bank will take this type of security for the purposes of affecting oil and gas interests.

\section{Worker's Compensation Board}

Section 126 of the Workers' Compensation Act ("WCA") creates a "super" priority in favour of the Worker's Compensation Board ("WCB") for the amount owing to the WCB by an employer. This super priority creates a fixed, specific and continuing charge in favour of the WCB on any property of the employer, including accounts receivable. This charge is payable in priority over all writs, judgments, debts, liens, charges, mortgages, rights of distress, or other claims and encumbrances of whatever kind. ${ }^{67}$ Section 128 of the WCA provides that where there is a purchase of the vendor's business, stock or equipment, the purchaser is liable to the WCB for any amounts owing to the WCB by the vendor, up to certain amounts, unless the purchaser has obtained a clearance certificate beforehand.

It is therefore necessary to search the WCB and it is not unusual to find outstanding amounts where a vendor is insolvent. It should be noted that while section 127(2) of the WCA states that the statutory charge does not attach against real property until a certificate or certified statement is filed in the relevant Land Titles Office, section 126 (1) clearly provides that the charge has priority to any assignment of personal property, which would include an assignment pursuant to a purchase of a production sales contract.

Searches of the WCB do not comprise a clearance certificate under section 128 unless that is specifically requested and received. Further, if the vendor does not maintain an account with the WCB but should, the search only indicates that no account is maintained. This does not mean that a prior charge does not exist. As well, amounts exigible by the WCB from an employer are based largely on self-assessment. An incorrect self-assessment will not be revealed in a search of the WCB, but the super priority still applies.

\section{Municipal Taxation Authorities}

The Municipal Taxation Act ${ }^{68}$ provides under section 111 that a tax certificate may be obtained from the municipal secretary of the relevant municipality showing the status of property taxes payable against the lands in question. Section 65 of the Land Titles Act provides that land in a certificate of title is subject to the implied exception of unpaid taxes. Section 124(1) of the Municipal Tax Act creates a special lien on an owner's interest in land and improvements thereon. This lien is not restricted to

\author{
65. Supra, note 37. \\ 66. Supra, note 64. \\ 67. Ibid., s. 126(2). \\ 68. R.S.A. 1980 , c. M-31.
}


property located in a municipality ${ }^{69}$ or buildings where the building is situated on land not belonging to the owner. All personal property on the premises belonging to the person assessed and used in connection for a purpose which the occupant is assessed under a business assessment is subject to a first charge under the Act. ${ }^{70}$ Therefore personal property such as batteries and pump jacks in one municipal district can be the subject of a lien arising out of tax arrears on real property in another municipal district.

Since it is common for vendors experiencing financial difficulties not to pay property or business taxes, it is usually prudent to search those municipal districts where significant facilities, such as gas plants and well batteries, are located. While the taxes outstanding are usually not excessive, they can be in the order of several thousand dollars and a purchaser will certainly question why tax arrears did not show up in his counsel's due diligence.

\section{Environmental Searches}

Pursuant to section 4 of the Land Surface Conservation and Reclamation Act, ${ }^{11}$ a reclamation certificate can be issued by the Land Conservation Reclamation Council to an operator when the Council is satisfied that the surface land is in satisfactory condition. No specific provision is made under the Act but a search may be conducted at the Council to ensure that reclamation obligations have been satisfied. Reclamation orders can also be searched.

Searches can also be made at the Pollution Control Division, Department of Environment for stop orders, emission control orders or chemical control orders directed against a person. ${ }^{2}$ The Pollution Control Division will issue a letter disclosing whether any stop or control orders have been issued against the owner or operator of the land in question. The search request must provide the registered corporate name of the party against whom the search is to be conducted. This is normally the operator.

A record of the licensed facilities under the Clean Air Act and Clean Water Act ${ }^{73}$ and any violations of the licensed conditions can be obtained from the Director of Standards and Approvals, Department of Environment.

\section{Energy Resources Conservation Board}

The Oil and Gas Conservation Act requires that the Energy Resources Conservation Board ('ERCB") maintain a record of licenses, permits, registration of unit operators and status of the well administration fee payable by well operators. ${ }^{74}$ Information on spud dates, production and spacing units is also obtainable from the ERCB.

69. Ibid., s. 124(4), s. 134.

70. Ibid., s. 125.

71. R.S.A. 1980 , c. L-3.

72. Issued pursuant to the Clean Water Act, R.S.A. 1980, c. C-13, s. 14; Clean Air Act, R.S.A. 1980 , c. C-12, ss. 13, 14; and Hazardous Chemicals Act, R.S.A. 1980, c. H-3, s. 6.

73. libid., ss. 3 and 4 .

74. R.S.A. 1980, c. O-5, ss. 14,49 and 53(2); the latter provision permits the ERCB to order the shutdown of a well for failure to pay the well administration fee. 


\section{Crown Royalty Searches}

The regulations to the Mines and Minerals Act ${ }^{75}$ provide that the Minister of Energy may make available information concerning royalties if the consent of the payor is obtained. Gas royalty inquiries are usually performed with the Gas Accounts, Minerals and Revenue Division of the Department of Energy. Such a search is done on a company-to-company basis and is not broken down into individual property royalties. Therefore the search is not particularly useful except where all of the assets of the vendor are being purchased.

Inquiries pertaining to oil royalties may be addressed to the Alberta Petroleum Marketing Commission ("APMC') with the consent in writing of the royalty payor. Petroleum royalty accounts are apparently maintained by the APMC by legal description of the property.

The foregoing searches may provide some indication of the royalty paying habits of certain vendors, but there are serious limitations on their usefulness. Defaults with respect to vendors and financial difficulties may become apparent, but there is no certainty of this. Section 39(1) of the Mines and Minerals Act ${ }^{76}$ provides that the Minister of Energy may recalculate the Crown's royalty at any time if the recalculation has been necessitated by a misrepresentation attributable to neglect, carelessness or wilful default or by fraud in the filing or supplying of any report under the Act (these categories seem to include every circumstance), or in any other case, within four years after the end of the month in which the Crown's royalty share was due. Even if it could be concluded by the searches that the vendor paid royalties on a timely basis, the reassessment rights of the Crown seem almost limitless. Section 44 of the Act provides that the Minister of Energy can cancel a lease for failure to comply with the Act or its regulations, which includes a requirement to pay royalties. This means that a purchaser can be faced with the obligation to repay a predecessor's back royalties or face the prospect of losing his lease.

\section{Employment Standards Code}

The Employment Standards Code provides a super priority provision in respect of wages, overtime pay, vacation pay and general holiday pay due or accruing to an employee. ${ }^{77}$ It appears to attach to personal property immediately, but not real property until it is registered..$^{78}$ This charge applies to a maximum of $\$ 7,500.00$, and at present, there appears to be no statutory mechanism for searching this potential charge. Inquiries can be made of the Employment Standards Branch, Regional Manager. Anyone who has employees will always owe them money for wages. Therefore a purchaser buying from a vendor in financial difficulties should always consider a hold back of $\$ 7,500.00$.

75. Supra, note 33; Alta. Reg. 163/84.

76. Supra, note 52 .

77. Supra, note 64 , s. 113.

78. Ibid., s. 114(2). 


\section{THE NATURE AND MEANING OF COMMON REPRESENTATIONS AND WARRANTIES}

Representations and warranties are generally regarded as statements of existing fact inducing contract which, if relied upon, are actionable. As discussed above, the purchaser requires representations and warranties as part of his pursuit of knowledge. A purchaser should therefore view his representations and warranties as a mechanism, to be used in parallel with due diligence, to verify his assumptions and reveal pertinent facts about the property and the vendor prior to closing. Representations and warranties dictate for the prudent vendor the degree of internal review that he must carry out to ensure that he can honestly give them. It is also in these provisions that the vendor's ongoing liabilities to the purchaser are generally defined. This ongoing liability only sets up a cause of action for the purchaser, but for many facts there may be no alternative because they cannot be verified, or verified at reasonable cost.

The representations and warranties in any agreement result mostly from the negotiation process between counsel, as opposed to that between the purchaser and the vendor. This is because most purchasers and vendors do not address their minds to the legalistic domain of representations and warranties and understandably usually leave this process to their respective council. Purchaser's counsel, in negotiating representations and warranties, must keep in mind what assumptions the purchaser has made about the vendor and the property, what knowledge is sought, and what risk the purchaser is prepared to take in terms of caveat emptor. The nature of the transaction may itself determine this. For example, sales by trustees in bankruptcy and receivers usually result in little in the way of representations and warranties, and this increased risk is usually reflected in the purchase price. On the other hand, the purchaser may have a sufficient degree of knowledge about the vendor and the property, or know that he is getting the property at a sufficiently low price, that he is not concerned about some of the usual representations and warranties. In these circumstances purchaser's counsel should clearly describe the risks associated in not obtaining the information which would have been provided by the appropriate representation and warranty, and whether this information can be confirmed by independent due diligence.

Representations and warranties generally fall into two categories. There are those representations and warranties that pertain to the vendor and those that pertain to his properties.

\section{A. REPRESENTATIONS AND WARRANTIES ABOUT THE VENDOR}

The following is a discussion of the meaning and subtleties of some of the typical representations and warranties that a vendor will make about himself and the transaction contemplated. Each one has a specific purpose in informing the purchaser.

\section{Due Incorporation, Organization and Subsistence}

Vendor is a corporation duly incorporated, organized and validly subsisting under the laws of its jurisdiction of incorporation and is duly registered in, is qualified to do business in, and is in good standing under the laws of the Province of Alberta.

This states that the vendor, in this case a corporation, has been properly formed and has not lost status as a corporation. "Duly incorporated" means that the corporation has been created by law by all necessary steps. The reference to jurisdiction of incorporation is required because a foreign corporation extra-provincially registered 
here does not maintain its corporate life in Alberta once it ceases to be under its jurisdiction of incorporation. "Duly organized" means that organizational matters have occurred, such as the issuance of shares and the election of directors, without which no individual may be legally available to execute documents on behalf of the corporation. A corporation might be duly incorporated but not duly organized. "Validly subsisting" means that voluntary or involuntary dissolution or voluntary liquidation proceedings have not commenced, and that the corporation has the ability to do business in Alberta, and can be sued in Alberta. The "good standing" provision establishes that the vendor and his corporate status is not threatened for failure to file returns. Corporate status is very significant because failure of corporate status can result in the vendor's property escheating to the Crown, ${ }^{79}$ and makes the vendor ineligible to hold Crown mineral leases ${ }^{80}$ or freehold certificates of title or caveats, ${ }^{81}$ or to transfer any of them. ${ }^{82}$ If the vendor is selling all or substantially all of his assets, the purchaser should obtain a covenant that vendor's corporate status will be maintained for a sufficient time after closing to ensure that follow up specific transfers can be obtained. It may be advisable to obtain the guarantee of a responsible party to this covenant.

It should be noted that section 281 of the BCA provides that a transfer of property by an extra-provincial corporation is not valid by reason only that such corporation was not then extra-provincially registered. This is of little practical comfort to a purchaser who cannot become a recognized lessee under Crown leases, or have caveats transferred to him, because appropriate extra-provincial registration was not maintained.

\section{Due Authorization}

The execution and delivery of this agreement has been duly authorized by all necessary corporate action required to be taken by Vendor and will not violate or conflict with its charter or governing documents, and Vendor has good right, full power and absolute authority to bargain, sell, transfer, assign and convey the Sold Assets for the purposes and in the manner provided for herein according to the true meaning and intent of this agreement.

This representation and warranty addresses a number of matters about which the purchaser cannot have knowledge. Is the corporate status of the vendor of such a nature that makes the transaction ultra vires the corporation? This is a legitimate concern where non-BCA entities are involved. Corporations incorporated under the BCA have the powers of a natural person, ${ }^{83}$ as do corporations under the Canada Business Corporations Act ("CBCA") diligence search of the vendor's jurisdiction of incorporation and a review of that jurisdiction's relevant legislation might suggest that the corporation has all the powers of a natural person. It does not confirm that, however, because the reviewer may not be competent in the law of that foreign jurisdiction, hence the need for the representation and warranty.

79. Business Corporations Act, supra, note 42, s. 221.

80. Mines and Minerals Act, supra, note 52, s. 24(2).

81. Land Titles Act, supra, note 49, s. 30.

82. Supra, notes 80 and 81 .

83. Supra, note 42 , s. 15.

84. R.S.C. 1985 , c. C-44, s. 16.

85. Section 16(3) of each of the BCA and CBCA provide that transfers of property are not invalidated by reason only that the transfer is contrary to the articles. 
It is normal for the purchaser to want the comfort of knowing that whatever restrictions exist internally in the corporate vendor to sell the property have been dealt with effectively. This is particularly the case where a corporation may be selling all or substantially all of its assets and a provision exists in the form of that found in section 183 of the BCA, which requires special approval of the shareholders. Other documents or agreements affecting the corporation, such as unanimous shareholder agreements or by-laws, which are not documents of public record, may require special corporate actions to be taken to authorize the corporation to sell the property.

The purchaser is protected to some extent by section 18 of the BCA, where the vendor is a corporation incorporated or continued under that statute. That provision is a codification of the "indoor management rule" at common law, which provides that a person dealing with a corporation is not required to enquire into its internal affairs to determine whether the corporation can be bound by an agreement, unless the person knew or ought to have known to the contrary. If the vendor is an extraprovincial corporation, or is a "non-standard" entity such as a trust company, insurance company, bank, Crown agency, railway, credit union, society or co-operative, there is always the fear that the laws pertaining to its incorporation might prohibit or affect the sale transaction. Extra-provincial corporations and non-standard entities are incorporated under other acts and no protection is then afforded by the BCA. There may or may not be equivalent protection under those other acts to section 18 of the BCA. In most cases it would be impractical for the purchaser or his counsel to review all the internal affairs of the vendor and any laws applicable to him to determine whether they conflicted with the purchase and sale agreement, or afforded protection in the same manner as section 18 of the BCA. Where there is doubt, an opinion of vendor's counsel is advisable. This is discussed below.

Quite aside from the problem of section 18 not applying to many entities who may not be subject to the BCA, as discussed above, it is difficult to know when the purchaser, by virtue of his position or relationship with the vendor who is a BCA corporation, knew or ought to have known, that the vendor did not take, for example, the appropriate internal corporate steps to approve the transaction. Is the transaction arm's length? Are there mutual directors or officers? Do any of the directors or officers of the purchaser own a significant number of shares of the vendor? Does the purchaser own any shares of the vendor? Any of these questions answered in the affirmative might preclude reliance on section 18.

It should be noted that the above representation and warranty refers not to the right, power and authority of the vendor to enter into the agreement, but rather to sell the assets being sold. For this reason, it is important for vendor's counsel to determine before the date of execution whether or not the representation will be true as of the date of execution by the vendor. Shareholder's resolutions may be required, such as pursuant to section 183 of the BCA. Otherwise, it is a representation and warranty upon which a purchaser could sue if he suffered damages as a consequence of its breach.

\section{No Conflict}

The consummation of the transactions contemplated hereby will not violate or conflict with any provisions of any agreement or instrument to which Vendor is a party by which it is bound, or any judgment, writ, decree, order, law, statute, rule or regulation applicable to Vendor.

It is this representation and warranty that sets up the protection a purchaser needs for the Pennzoil v. Texaco-type situation, where a purchaser might unwittingly be committing the tort of intentionally interfering with contractual relations. The pro- 
vision tells the purchaser that he is not interfering with another purchaser who has an agreement in place to buy the same assets, or that the purchaser is not buying assets which are subject to a confidentiality agreement with other joint owners of the vendor, such as is often the case with geological and seismic information. These are issues which due diligence may not reveal. The provision also goes to the ability to sell the property when security instruments, such as floating charge debentures, exist. There may be writs of execution or court orders, such as injunctions or orders for specific performance, which may conflict with the transaction, and which are registered in an unsearched judicial district.

It should also be noted that the provision tells the purchaser that the vendor is not breaching any agreement by assigning the assets. Most oil and gas industry agreements contain a requirement of a party to notify and obtain the consent of the other parties before assignment. This is common in most operating agreements, farmout agreements, pooling agreements and some freehold leases, such as those with PanCanadian Petroleum Limited and Dome Petroleum Limited (or their predecessors or successors) where they are a lessor. It is typical to not obtain such consents before closing, and if not obtained, the representation and warranty will be untrue at the time of closing. A purchaser could suffer significant damages from this breach if he failed to get recognized in a contract after closing. The representation and warranty should be carefully considered in this context by a vendor.

\section{Enforceability}

\section{"This agreement has been duly authorized, executed and delivered by Vendor and constitutes a valid and binding agreement of Vendor enforceable against it in accordance with its terms."}

It can be said that this representation and warranty essentially deals with the substance of the items which pertain to representations and warranties 1 through 3 above. It does not deal with all of item 3 above as the agreement could still be enforceable, although it may be in violation or conflict with other agreements and laws. There is often the concern that such a provision is a statement of law and not fact, and as a consequence no reliance can be placed upon it. ${ }^{86}$ The blurring of fact and law can affect many representation and warranties. It is therefore customary in more significant transactions, or in transactions where there is a concern about the vendor having capacity or having taken the proper corporate steps to enable itself to sell, to require an opinion from vendor's counsel to the effect that the agreement is enforceable. These opinions are of particular importance where the vendor is going out of business, is insolvent, is a receiver or trustee in bankruptcy, or is a corporation about which the purchaser has enough knowledge to concern himself that the representation and warranty is insufficient and reliance on section 18 of the BCA is not available or prudent.

A practice has developed of qualifying the representation and warranty by stating that specific performance, injunction and other equitable remedies may not be available, and that enforcement may be limited by laws affecting creditor's rights generally, including bankruptcy, insolvency, reorganization and related laws. While such qualifications are acceptable in enforceability opinions, they are troublesome in an enforceability representation. One of the purposes of representations and warranties is to encourage disclosure, and if a party knows of a fact that will affect enforcement 
of its obligations because of the application of equity or creditor's rights law, then it seems inappropriate that it should be able to hide behind the qualifications and avoid the disclosure. On the other hand, it might be said that the qualification is necessary because the law does have uncertainties, and the provision, being largely a legalistic matter rather than a factual one, requires the qualification in order to be an accurate statement.

Purchasing from privately appointed receivers is particularly troublesome because one cannot know whether the receiver has any authority at all. Enforceability opinions from the receiver's counsel are generally advisable. Where the receiver is court appointed, the relevant court order should be reviewed to ensure that such court order protects the purchaser from liens, inchoate or registered, and in particular, operator's liens. A court order vesting the properties in the purchaser free and clear of all liens is usually a condition precedent to closing.

Purchaser's counsel has to weigh all of the foregoing factors in determining whether an enforceability opinion of vendor's counsel is advisable.

\section{Governmental Approval}

No authorization or approval or other action by, or notice to or filing with, any governmental authority or regulatory body exercising jurisdiction over the Sold Assets is required for the due execution, delivery and performance by Vendor of this agreement, other than authorizations, approvals or exemptions from requirement therefore, previously obtained and currently in force.

This provision tells the purchaser that the vendor is not the type of person that must obtain the consent of government or a regulatory body to perform the agreement, such as is the case with utilities. Section 99 of the Public Utilities Board Act ${ }^{87}$ ("PUBA") provides that wherever the owner of a public utility is authorized to unite with the owner of another public utility, consent of the Public Utilities Board ("PUB") is required before the transaction can be effective. This is a troublesome provision primarily because the definition of a public utility in the $\mathrm{PUBA}^{88}$ and the definition of an owner of a public utility" and the corresponding definitions of "gas utility" and "owner of a gas utility" in the Gas Utilities Act" ("GUA") are so broad that virtually any oil and gas entity that operates a gas facility, gas pipeline, gathering system and the like, or owns any entity that owns any of those, would be caught by the section. The GUA incorporates by reference section 99 of the PUBA..$^{91}$ Section 99 of the PUBA is a separate problem and simply must be addressed in every transaction. Declarations that section 99 does not apply to applicants in a particular transaction can normally be obtained by application to the PUB. Sections 25.1 of the GUA and 99.1 of the PUBA, which provisions require PUB approval to the sale of any assets by owners of utilities, only apply to owners deregulated by regulation passed by the Lieutenant Governor in Council. These can be easily reviewed by counsel during due diligence.

87. R.S.A. 1980 , c. P-37.

88. Ibid., s. 1(j).

89. lbid., s. 1 (g).

90. R.S.A. 1980, c. G-4.

91. Ibid., ss. 50, 51. 
This representation and warranty when given by a purchaser also addresses Investment Canada $A C^{22}$ and Competition $A{ }^{23}$ approvals.

The representation and warranty presumably also covers any Crown consents that may be required to the transfer of assets. ${ }^{94}$ The Clean Air Act ${ }^{95}$ and Clean Water Act ${ }^{96}$ prohibit the transfer of licenses issued under them. The Oil and Gas Conservation $A c t^{97}$ requires the consent of the ERCB to any well license transfer. The ERCB has declared its intent to restrict its consent to well license transfers, so vendors can no longer assume the assignment will be automatic.98

\section{ARTC Eligibility}

Vendor is not an "above-limit corporation", a "restricted corporation" or a member of a "restricted partnership" and none of the Sold Assets are a "restricted resource property" as such terms are defined in the Alberta Corporate Income Tax Act.

This representation and warranty is a very significant one for purchasers who want to continue to be entitled to ARTC in respect of the properties purchased. ${ }^{99}$ The ARTC can comprise a significant portion of the value in a purchase of producing oil and gas properties. The financial statements of public corporations will usually give an indication to the purchaser of whether or not the vendor can pass on property which will be entitled to ARTC. However, such information may not be up-to-date and in many instances, the vendor may be a private corporation. Using due diligence to determine ARTC eligibility may mean conducting an audit of the vendor, which is usually inappropriate, except in purchases of all or substantially all of the assets of a vendor. With two exceptions, it is a representation and warranty that the vendor should be able to give without much difficulty.

The first exception is the reference to the sold assets not being a "restricted resource property". The way the above representation and warranty reads, the vendor is warranting that the property being sold is not "tainted" in terms of eligibility for ARTC. Generally speaking, any oil and gas property is "tainted" if it was owned by a corporation on August 24, 1982 that was then an "above-limit corporation" or an "above limit partnership", or was sold after April 7, 1986 by a corporation that was at the time of sale a "restricted corporation" or by a partnership which was at the time of sale a "restricted partnership"'.100 These are basically entities that have exceeded certain financial limits based on Alberta Crown royalties which disentitles them to ARTC. Any property that they sell is likewise disentitled. A vendor making the representation and warranty must be careful that the property he is selling was not tainted by a predecessor in title, and this requires a careful review of the technical rules and a thorough understanding of the ARTC status of predecessors in title.

92. Supra, note 1, s. 39(1).

93. Supra, note 2, ss. 64-72.

94. See also consents required of the Federal Crown under the Canada Petroleum Resources Act, R.S.C. 1985, c. 36 (2nd Supp.); and Indian Oil and Gas Act, R.S.C. 1985, c. I-7.

95. Supra, note 72, s. 6.

96. Jbid., s. 6.

97. Supra, note 74, s. 18.

98. See Energy Resources Conservation Board, "Recommendations to Limit the Public Risk from Corporate Insolvencies Involving Inactive Wells." - December 1989.

99. Supra, note 38 .

100. Ibid. 
The second exception has to do with how close the vendor is to the ARTC limits, and the risk that a later royalty reassessment could push the vendor "above limit." The property would then be retroactively "tainted" as not being entitled to ARTC, and the purchaser could suffer substantial damages. Purchasers who are aware of vendors in this circumstance should consider longer survival periods on the representation and warranty, having regard to the reassessment provisions in the Mines and Minerals Act ${ }^{101}$ and the Alberta Corporate Income Tax Act. ${ }^{102}$

\section{Residency}

Vendor is not a non-resident of Canada within the meaning of Section 116 of the Income Tax Act.

The purpose of this provision is to give the purchaser some basis for stating that he is not liable for withholding tax if it turns out that the vendor is a non-resident. Due diligence can verify this to a certain extent.

It is customary that several of the foregoing representations and warranties, modified appropriately, are also given by the purchaser to the vendor, for the same reasons stated above.

\section{B. REPRESENTATIONS AND WARRANTIES ABOUT THE PROPERTY}

The following representations and warranties considered are those which pertain to the relationship of the vendor to the properties being sold, and the status of the properties themselves. If the property being sold comprises all or substantially all of the assets of the vendor, a number of statutory provisions are triggered. These include not only section 183 of the BCA above-mentioned, but also certain other statutes such as the Bulk Sales Act 103 ("BSA"), WCA 104 and the Income Tax Act'05 ("ITA"). The applicability of the BSA and WCA must be determined in every sale and if they apply, provision must be made for compliance with the statutes, which may include clearance certificates under the WCA and BSA statements and declarations. There is legitimate doubt as to the applicability of the BSA to oil and gas purchase transactions but a discussion of that issue is beyond the scope of this paper. If the purchaser is intending to obtain the benefit of the vendor's tax pools such as the Cumulative Canadian Development Expense, ${ }^{106}$ Cumulative Canadian Exploration Expense ${ }^{107}$ and Cumulative Canadian Oil and Gas Property Expense ${ }^{108}$ pursuant to the successor elections under paragraph 66.7 of the ITA, representations as to the magnitude of the pools are usually obtained, along with covenants on successor elections, fiscal year end determinations, income tax return filings and re-assessment contingencies.

The following are typical representations and warranties that pertain to property:

101. Supra, note 52.

102. Supra, Note 38, s. 43.

103. R.S.A. 1980 , c. B-13.

104. Supra, note 64, s. 128.

105. Supra, note 36.

106. Ibid., para. 66.2 .

107. Ibid., para. 66.1.

108. Ibid., para. 66.4 . 


\title{
1. Title Maintenance
}

\begin{abstract}
Vendor has done no act or thing and suffered or permitted no act or omission whereby its title to the petroleum and natural gas rights may be cancelled or determined, nor has Vendor encumbered or alienated the same or any interest therein other than as set out in Schedule " $\mathrm{A}$ ", and the petroleum and natural gas rights are now free and clear of all liens, encumbrances, royalties and third party claims by, through or under Vendor other than as set out in Schedule " $\mathrm{A}$ ", nor is the interest of Vendor in the petroleum and natural gas rights subject to reduction by virtue of the conversion or other alteration of the interest of any person other than as set out in Schedule " $A$ ";
\end{abstract}

This representation and warranty speaks a great deal about title. The first part essentially means that the vendor has done everything necessary to maintain good title, whether the vendor is the operator or not. The operator usually administers leases, and this provision means that the vendor has closely monitored the operator's conduct to ensure that no payments were missed or performance not done that could imperil title, including title curative efforts. Consideration by the purchaser must be given to including the vendor's related predecessors in this provision, such as parents or affiliates. The value of the provision is restricted by the period of time during which the assets were held by the vendor. Some divestiture programs put properties into shell companies before going to market as a means of limiting liability in title and other representations and warranties. The provision speaks only to real property and not personal property. Certain types of personal property are extremely critical in a purchase, such as contracts for the sale of production, because they govern the flow of money. Title to personal property is dealt with differently, as discussed below.

There is often an exception made to the second part of this provision to include the concept of "permitted encumbrances" to deal with such matters as easements, rights of way, rights reserved in the Crown to terminate any lease, the right of a government to levy taxes on oil and gas rights, contracts for the sale of petroleum substances where the lands are dedicated to production contracts, undetermined or inchoate liens in favour of operators, reservations, limitations, provisos and conditions in any original grant from the Crown, provisions for penalties and forfeitures under agreements applicable to the assets and the terms and conditions of the title documents themselves. The purchaser must be careful that any definition of permitted encumbrances is not so broad as to include encumbrances about which he would want to be informed. Forfeitures and penalties outstanding, and dedicating of lands to gas contracts, are very relevant to a purchaser.

The last part of this representation and warranty speaks to reduction by virtue of conversion or other alteration of interest of any person, including predecessors in title, and is not restricted to a "by, through and under" concept. This means that the vendor is warranting this aspect of predecessors' title, and should be careful in so doing.

A variation of the above representation and warranty is one which states:

Schedule " $A$ " is a true and accurate summary of the lands and leases and vendor's interests therein and the encumbrances thereon.

Although such a clause seems innocuous, it is very likely a form of absolute title representation.

\section{No Default}

Vendor is not in default under any leases or any agreement affecting the sold assets to which it is a party or by which it is bound, or with respect to any law, statute, order, writ, injunction or decree of any governmental agency or any Court. 
This representation and warranty is very restricted its in scope. For example, the vendor may have been served with notice and made aware of a default but if the vendor is of the opinion that he is not in default, then he can make the statement. Indeed, it is common to see in the notes to the financial statements of public companies a list of pending litigation against the company accompanied by a statement of management that they believe there is no merit to the claim. In this circumstance, it would be very odd if a vendor would say anything different in a purchase and sale agreement. A prudent purchaser will therefore always require a vendor to state that not only is he not in default of agreements and laws, but also that he has not received notice of an alleged default. This "notice" concept is fundamental to many of the representations and warranties that a prudent purchaser should obtain in his pursuit of knowledge. Requiring disclosure on notices of default alerts the purchaser to the state of mind of others who have an interest in the properties or may have an adverse claim to them, and permits the purchaser to review the relevant facts so that he can come to his own conclusion. This subtle difference in the wording between the vendor's awareness of a state of facts and the vendor's belief in his legal position can have a dramatic difference in the information to which the purchaser will be exposed. If the vendor is not the operator, the provision is of limited use to the purchaser because the vendor may not have been appropriately informed by the operator. The purchaser may want to make reference to the operator as well in the provision, and this is often accomplished by using words such as "to the best of the knowledge" of vendor, or "vendor is not aware". See also the discussion under representations and warranties concerning no conflict or violation with agreements, above.

\section{No Litigation}

No suit, action or other proceeding is pending or to the best of Vendor's knowledge threatened before any Court or governmental agency or tribunal which might have a material adverse effect on the Sold Assets.

This representation and warranty may appear to simply duplicate the "no default" representation and warranty discussed above. The difference is that a lawsuit may not be speaking to a default but may merely be seeking a declaration as to the relationship of the vendor to another party. The obvious example is where a delay rental payment has been missed under a freehold "unless" type lease and legal proceedings have been commenced or threatened to seek a declaration as to the termination or existence of the lease. This is a necessary representation and warranty, particularly when due diligence searches are not being carried out in every judicial district in the province or other jurisdiction where the vendor might be sued. Further, searches of clerks of court for actions where a party is a plaintiff or a defendant are not always reliable. The person executing the search might have the correct name of the party being searched, but that does not mean that a person who has sued has identified a party correctly, or that the clerks of court have carried out the search with precision, with the result that some searches might not disclose actions that have been commenced. It should be noted that legal proceedings can be commenced without the vendor being served with notice. The complaining party has a period of time in which he can serve proceedings and service can be other than personal service. The word "pending" is troublesome because it may include actions that have not been issued. A vendor must also be aware that the provision includes proceedings commenced against his operator, or a person who holds the property in trust for the vendor, and the vendor may have no knowledge of the matter unless he happens to be informed by one of those parties. 


\section{Good Title to Tangibles and Miscellaneous Interests}

Vendor has good and marketable beneficial title to tangibles and the miscellaneous interests, free and clear of any liens, charges or encumbrances.

This representation and warranty is necessary because title to personal property, for several reasons, can never be conclusively determined. The word "tangibles" is usually a defined term which includes equipment from the wellhead and beyond used in the production of petroleum substances. This typically includes wellhead equipment, pumps, treating, processing and compressing equipment, tanks, boilers, batteries and the like. It is quite normal for a vendor to own varying percentages of equipment beyond the wellhead, which may bear no relationship to the interest in the petroleum and natural gas rights being purchased. If so, the interest in each particular tangible should be described, usually in a schedule. Miscellaneous interests normally include items such as seismic, geological, geophysical, engineering and other data, accounting records, licenses, permits, construction, ownership and operating agreements, production held in inventory, gas purchase contracts, choses in action, surface rights, and various types of intellectual property. The purchaser must be satisfied that the vendor has not assigned as security his production purchase contracts. There is no current compulsory registry for this, and only due diligence of the vendor's records and representations and warranties can protect the purchaser. The vendor must be careful to ensure that although he may have property rights in such things as seismic information, he may not have trading rights to that information and cannot sell it, or may be bound by confidentiality agreements.

\section{Financial Commitments}

There are no accrued drilling obligations in respect of the Sold Assets that have not been satisfied and there are no existing authorizations for expenditures nor any other financial commitments which are now outstanding or due, or hereafter may become due in respect of the Sold Assets, in excess of $\$ 10,000$.

One of the vendor's goals in selling properties is to transfer as much of the obligations of those properties as possible to the purchaser. If the vendor has committed himself to an expenditure, such as the drilling of a well pursuant to an operations notice under an operating agreement or as a farmee in a farmout agreement, he usually intends to novate the purchaser into that obligation and novate himself out. The purchaser quite often, in preparing his economic evaluation of the properties, does so on the assumption that there are no accrued drilling commitments or financial expenditures for which he will be liable. It is therefore crucial that representations and warranties such as this are present so that financial commitment items can be identified and dealt with by the parties. The question the foregoing representation and warranty gives rise to is contained in the words "or hereafter may become due" in respect of the sold assets. Presumably this portion of the provision is referring to accrued obligations which have not yet become due as opposed to obligations which may become due in the future and over which the purchaser will have control. It also is not restricted to the vendor's liability for financial commitments, but any joint owner's liability. The provision should be restricted to the vendor's liability. Further, vendors must be mindful of the expenditure limits of operators contained in operating agreements. These permit operators to expend money up to certain amounts without seeking the prior approval of non-operators. The amount of $\$ 25,000$ is a typical limit.

\section{Operations}

The wells included in the Sold Assets and the tangibles have been drilled, completed, shut-in, abandoned, suspended, operated and maintained, as the case may be, in accordance with good oilfield practice and the Sold Assets have been administered, owned and operated in accordance with all applicable laws, rules, regulations, orders and lawful directions of governmental and other competent authorities. 
This is a very important representation and warranty for the purchaser. It is impossible by due diligence for the purchaser to determine whether the vendor or its predecessors have complied with the myriad of laws that are applicable to the oil and gas business. Violations of laws in the past could have very serious ramifications to production in the future. Adjusting operations to comply with laws may mean dramatically higher operating costs with the result that the affected properties should not have been attributed the value which the purchaser gave them in his economic analysis. Many operators avoid abandoning wells as long as possible and expect as a vendor to pass on these obligations to the purchaser. Other authors have discussed this type of representation and warranty as it affects environmental issues. ${ }^{109}$ The status of "orphan" wells is now becoming more clear pursuant to the proposed amendments to the Oil and Gas Conservation Act ${ }^{10}$. The above provision, it should be noted, ignores whether the vendor is the operator or not, and speaks to all predecessors' activities as well. The provision is often softened by restricting it to material matters.

The provision is also significant in that it implies the vendor has paid Crown royalties required to maintain Crown leases. Section 44 of the Mines and Minerals $A c t^{\prime \prime \prime}$ provides that the Minister of Energy can cancel a lease for failure to comply with the Act or its regulations, which include a requirement to pay royalties. Independent determinations of whether or not a vendor has appropriately paid royalties on any given well is difficult and not conclusive, as previously discussed.

Passive investors invariably have their royalty paid by someone else, such as the operator, who nets the royalty out of revenue. It may not be feasible to review royalty information about the operator, who might care less about a sale by a joint owner. The calculation of royalties is not a simple matter ${ }^{112}$ and the time and effort involved in calculating whether or not appropriate royalties have been paid is impractical. Section 39(1) of the Mines and Minerals Act permits a reassessment by the Minister of Energy on any royalty calculation at any time due to a misrepresentation attributable to neglect, carelessness or wilful default or by fraud, or in any other case, within four years after the end of the month in which the Crown's royalty share was deliverable. The use of the words "neglect, carelessness or wilful default or by fraud" in this section is troublesome to a purchaser. It is hard to imagine a circumstance which falls outside of this provision with the result that practically there is no time limit on the Crown's right to reassess royalties for any given Crown lease. The survivability of representations and warranties in any purchase and sale agreement is always a negotiated item, and seems to range anywhere from six months to three years. Since reassessments may be substantial, and failure to pay can result in lease termination, purchasers should always consider negotiating an unlimited survival period for any representation and warranty pertaining to Crown royalties, or providing for a separate and specific indemnity if the reliance issue might prejudice the usefulness of the representation and warranty. It is common in share purchases of companies to obtain survival periods in respect of tax matters at least as long as the applicable reassessment period. Since royalties, like income taxes, are essentially government levies,

109. A.J. Hudek \& J.R. Paulus, "Current Environmental Regulation of the Alberta Oil \& Gas Industry and Emerging Issues", (1990) 28 Alta. L. Rev. 171 at 230.

110. Supra, note 74.

111. Supra, note 52.

112. See B.R. Emes, "Provincial Royalties and Credits" (1988) 27 Alta. L. Rev. 51. 
there is no conceptual basis for treating representations and warranties, or indemnities, in respect of Crown royalties in asset purchases any different from income taxes in share purchases.

\title{
7. Condition of Assets
}

\begin{abstract}
All producing wells on the lands and the tangibles operated by Vendor, or where such wells or tangibles are operated by operators acting on its behalf, to the best of Vendor's knowledge, are in good and operable condition, and are not subject to any production or other penalties imposed by agreements affecting the Sold Assets or applicable laws.
\end{abstract}

If the purchaser is assuming that he will continue to be able to operate the properties as they are being operated, on site inspection may not reveal many of the serious flaws that can be present in equipment, particularly gas plants where systems are complex. If the purchaser wants some comfort that he is buying more than salvageable junk, he will usually want a representation and warranty of this nature. This requires the vendor to do a detailed review of the condition of its wells and tangible equipment which usually means extensive inquiries of its engineering staff. The provision extends to matters such as proper completions downhole, pipelines appropriately protected from corrosion, wells within target areas, no past overproduction and no penalties under operating agreements. It is this type of representation and warranty, along with one stating that operations have been conducted in compliance with all laws, that lead to numerous claims by purchasers against vendors. This problem is quite often dealt with by restricting the provision to material matters such that immaterial claims are to be ignored.

\section{Taxes}

All ad valorem, property, production, severance and similar taxes, and assessments attributable to, or measured by, the ownership of property or production of petroleum substances or any of them, or the receipt of proceeds therefrom, have been properly paid and discharged in respect of the Sold Assets.

This representation and warranty addresses such matters as freehold mineral rights tax pursuant to the Freehold Mineral Rights Tax Act $t^{13}$ and property taxes and business taxes which are leviable by local government authorities. It is not restricted to the vendor's role in these matters, but also his operator, or anyone who is responsible for paying such amounts on the vendor's behalf. Most freehold leases provide that the lessor, who is a registered owner, shall pay the freehold tax, but in practice most of the lessees pay this tax on behalf of the freehold owner and withhold from royalties that amount of the tax for which the lessor is responsible, which is usually a percentage equal to his percentage royalty. This provision is also important for purchasers where there are substantial assets located in various municipalities throughout the province. Local taxation authorities have the ability to levy taxes on facilities, including gas plants, and like most taxation statutes, confiscation of the property being taxed is the ultimate remedy of the taxation authority. Due diligence inquiries of taxation authorities in the applicable districts are usually carried out where significant assets are located. It is common for insolvent vendors not to have paid property taxes for extended periods. 


\section{Undisclosed Matters}

There is no circumstance, matter or thing, known to Vendor, which if known to Purchaser could reasonably be expected to affect the decision of Purchaser to purchase the sold assets for the purchase price.

This type of representation and warranty comes in many forms and is sometimes reversed so that the vendor asks the purchaser whether there is anything known to the purchaser that would affect the vendor's decision to sell. The provision goes beyond undisclosed liabilities and speaks to the business acumen of the deal. Although the vendor or purchaser may be flattered that the other would ask him this, it is impossible and not reasonable for either to know what might be necessary for the other to know. Most purchase and sale transactions arise because there is an honest difference of opinion between the vendor and purchaser as to the value of the properties. There are an unlimited number of factors behind such opinions. An obvious example is where the purchaser thinks that he can increase the productivity of lands in an inexpensive manner by simply increasing the pump stroke in wellhead pumps, or may know that by infill drilling or horizontal drilling, the recoverable reserves can be substantially increased. The purchaser should not have to tell the vendor that he could get a much higher price if he wanted.

The vendor may be convinced that the production of the properties will decline very rapidly in the future and therefore the purchase price is very attractive to him. He should not be required to divulge that sort of information, or be at risk for not divulging it to a prospective purchaser, if the representation and warranty is to be reversed. These types of representations and warranties are usually found in equity financing transactions, where prospective shareholders are seeking business comfort from the company in which they are investing. The present and ongoing relationship of a company and its shareholders is substantially different from that of a vendor and purchaser and such representations and warranties are rarely appropriate in sale transactions.

A variation of such representation and warranty is where the vendor states that there are no undisclosed liabilities of which the purchaser should be made aware. This may be impossible for a vendor to assess because it requires the vendor to be put into the shoes of the purchaser and understand every factor that caused the purchaser to make its decision to buy. Ownership always entails risk. It is more appropriate that the purchaser cover his concerns by more specific representations and warranties so that these may be properly considered by a vendor. Over generalizing any representation and warranty leads to the risk that a vendor will underestimate its scope and not consider significant matters encompassed by it. This does no service to the purchaser. A further variation is where the vendor states that he has made available to the purchaser all of the vendor's records in relation to the property, which may or may not be appropriate. This would include the vendor's internal evaluations which he may wish to keep private for obvious reasons.

\section{Deficient Take-or-Pay Contracts}

\footnotetext{
Vendor is not aware of nor has it received any notices from a purchaser of production that recovery of petroleum substances constituting take or pay gas cannot be achieved within the time periods required under production sales contracts pertaining to the Sold Assets, or that the purchasers of such petroleum substances contend that the reserves dedicated to such contracts are deficient, and Vendor is not producing petroleum substances from the Sold Assets to meet take or pay delivery obligations associated with other production sales contracts.
} 
This is a representation and warranty that is very important where some of the sold assets may comprise "deficient" gas sales contracts where the buyer of such gas may not be able to recover all of his take or pay, or prepaid, gas. This matter is discussed later in this paper.

\section{Gas Balancing}

There are no gas balancing or gas banking agreements by which Vendor is bound or which pertain to the Sold Assets.

The shortcomings of operating agreements in respect of the production of gas from jointly owned property has resulted in a number of gas balancing contracts. ${ }^{114}$ The vendor will want the purchaser to assume any obligations under such agreements, and the purchaser, particularly if he is not the operator, will want to know how such gas balancing agreements affect his future production rights. This type of representation and warranty has numerous variations, including the following:

Purchaser will not be required or liable to pay a share of expenses disproportionate to its share of production of petroleum substances form the Sold Assets.

or:

Vendor has not produced from the Sold Assets more than that which it is entitled to produce by agreement or law where such over-production may adversely affect future production rates.

\section{Production Purchase Contracts}

Other than as disclosed is Schedule " " ", Vendor is not obligated to sell or deliver petroleum substances produced from the Sold Assets to any person pursuant to agreements which cannot be terminated on 30 days notice or less.

This provision ensures the purchaser that the producing properties being purchased are not dedicated to long term contracts about which the purchaser has no knowledge. In his economic evaluations, the purchaser may have assumed that he can sell the production to anyone he pleases. Many gas purchase contracts have take or pay provisions which could result in not receiving full value for future production. Indeed, many long term gas purchase contracts entered into today have dedication provisions which prevent the owner of those reserves from selling production except to the purchaser to whom the reserves are dedicated. Such contracts may be extremely unfavourable to a purchaser if they are subject to poor prices and low rates of take. Knowledge of such contracts is fundamental to the purchaser's decision to buy.

It should be noted that the foregoing representations and warranties are not intended to be a list of exhaustive or adequate provisions for every purchaser's needs. That will always be determined by the knowledge requirements of the purchaser, his sophistication, negotiating position and the degree to which he will accept risk. It is customary for vendors to object to the effort required by them to review and deal with representations and warranties. The vendor has to undertake due diligence of his own to make sure that he can give representations and warranties and may not have the manpower or the inclination to do so. Some vendors will too readily accept stringent representations and warranties without addressing the meaning of each of them, or understanding the subtleties of wording, thus frustrating the purchaser's search for knowledge.

114. See J.J. Park, "Marketing Production from Joint Property: the Past, the Present and the Future" (1990) 28 Alta. L. Rev. 34. 
It seems to be the case that there is no such thing as a comprehensive purchase agreement which will protect the purchaser from every risk, unless that risk is identified before contracting. Counsel to every purchaser should make it clear that due diligence beforehand, appropriate conditions precedent and properly drafted representations and warranties are the best means of protecting the purchaser. Similarly, vendor's counsel must ensure that the vendor understands what is required of him in the purchase and sale agreement in terms of reviewing his own affairs before giving representations and warranties and accepting the ongoing risks associated with them.

\section{INDEMNITIES}

Indemnities in purchase and sale agreements are simply provisions whereby one party protects the other from damages or losses that are a consequence of the ownership of the property and the transaction of purchase and sale. They do not have any purpose in providing knowledge, as in the case of representations and warranties, and have the narrow purpose of allocating risk. Indemnities allocate risk by creating a basis for causes of action and therefore are subject to the same enforcement problems as discussed with representations and warranties above. The following is a discussion of how the use of broad indemnities in many agreements confuses risk allocation.

\section{A. PROBLEMS WITH BROAD INDEMNITIES}

A very common practice has developed amongst oil and gas practitioners to include broad indemnities in purchase and sale agreements. The most common form of indemnity used is fraught with problems. The typical indemnity reads as follows:

Vendor remains liable for and agrees to and does hereby indemnify and save harmless Purchaser from and against all liability, loss, costs, claims or damages, absolute or contingent, of whatsoever nature, including fees on a solicitor/client basis, arising out of benefits or obligations or any act, omission, matter or thing relating to the sold assets done, omitted, occurring or accruing prior to the effective time. Purchaser shall be liable for and shall and does hereby indemnify and save harmless Vendor from and against all liability, loss, costs, claims or damages, absolute or contingent, of whatsoever nature, including fees on a solicitor/client basis, arising out of benefits or obligations or any act, omission, matter or thing relating to the sold assets, done, omitted, occurring or accruing subsequent to the effective time.

A superficial review of the provision suggests to the reader that it is merely a mechanism to allocate risk of ownership of the sold assets according to the point in time when title is effectively transferred. Closer scrutiny of the provision shows that it goes far beyond what most vendors or purchasers would expect.

The indemnity basically provides that the vendor will be responsible for everything in respect of the sold assets prior to the effective time, and the purchaser afterwards. This concept is very difficult to reconcile with the representations and warranties. For example, although the vendor intends to limit his liability by representing and warranting that the sold assets are now free and clear of all liens, encumbrances, royalties and third party claims by, through or under vendor, he is by giving the indemnification stating that he will be responsible for all of the defects in title that occurred prior to the effective time. This would include overriding royalties or encumbrances which were not created by, through or under the vendor, failures to pay delay rental payments or other payments the effect of which is to automatically terminate freehold leases, gaps in the chain of title where no documentation exists, 
or any of the other myriad of title problems that can affect oil and gas properties. Included would be those defects caused by predecessors in title of the vendor, no matter how far removed.

The indemnity is clearly not limited to title matters. If the vendor does not operate the properties, and gives a representation and warranty that to the best of his knowledge, the operator operated the properties in accordance with applicable law and good oilfield practices, and unbeknownst to the vendor the operator had broken the law in many significant ways, is not the vendor liable under the indemnity because it essentially makes him responsible for anything that occurred prior to the effective time, despite the warranty still being true? If a producing zone was damaged by an improper completion technique which will result in greatly reduced production unless a new well is drilled, is the vendor to be liable for this notwithstanding that this matter may not have been addressed in the representations and warranties, or that the purchaser had full knowledge of the circumstance? It is also possible to read the indemnity as making the vendor liable for the purchaser's expenses incurred in respect of the sold assets prior to the effective time, such as purchaser's legal fees in drafting the purchase and sale agreement and implementing it, due diligence costs and other expenses. It would be a surprised vendor who is told the indemnity causes this liability to be his. The possibilities for the vendor incurring liability pursuant to such an indemnity are limited only by the imagination of the purchaser's litigation counsel.

It is not clear how such an indemnity can be reconciled with representations and warranties. Representations and warranties are usually drafted with precision so that the vendor knows exactly what he is saying to the purchaser, and no more. What is the purpose of the representations and warranties if the indemnity makes the vendor liable for every occurrence, or every omission, prior to the effective time, which would include everything addressed and not addressed in his representations and warranties? The best construction of all written instruments is to make all parts agree. ${ }^{115}$ A court will strive to avoid an interpretation which renders provisions of contracts inconsistent with other provisions and will construe an agreement as a whole so that all parts of it are in harmony with each other. Using these principles, a court might consider that the parties intended their representations and warranties to address certain specific subjects such as title, and that the indemnity was not intended to impose liability on the vendor for every other title matter. In other words, if a representation has occupied a field, the indemnity is not applicable to that field. But the indemnity certainly does not read that way, because it goes to great pains to be broad. Further, if the representations and warranties occupied every field of liability, then the indemnity would be superfluous.

There are further problems with reconciling the indemnity. Unlike the way representations and warranties are normally treated, there is no survival period on the above indemnity, and therefore the vendor has a liability which goes on forever, except to the extent that it might be limited by statutory limitations. What then is the purpose of limiting the representations and warranties by time if that is meaningless in light of the indemnity? It may be that the indemnity and representations and warranties cannot be reconciled, and a court would have to prefer one over the other.

Further, the above indemnity is clearly an expansion of the common law as to what damages are recoverable in the case of a breach. There are two common law principles that govern recovery of damages for breach of contract. First, the party is to be put

115. Cooke v. Anderson, [1945] 1 W.W.R. 657 (Alta. C.A.). 
in the same position he would have been had the contract been performed, so far as can reasonably be done by money. ${ }^{116}$ Second, not all types of damage are compensated. If the damage is considered by the court not to be sufficiently connected with the breach, it is considered to be too remote. Only those damages which reasonable persons contemplated at the time of making the contract are recoverable. ${ }^{117}$ The above example of the indemnity speaks of damage of "whatsoever nature, contingent or absolute". These words seem to extend the remoteness and measure of damages far beyond the common law test which is tempered by reasonableness. The reference to recovery of solicitor/client fees would presumably include legal fees not associated with a lawsuit, which would include those legal fees charged by purchaser's counsel who after closing might have to review something to do with the properties which occurred prior to the effective time.

The foregoing problems arise because the broad indemnity seems conceptually inconsistent with one of the purposes of representations and warranties. One of the fundamental goals of a vendor is to unload liabilities, accrued and unaccrued, and the representations and warranties, among other provisions in the agreement are intended to define those liabilities for which a vendor is willing to remain responsible and those which (by not being addressed in the representations and warranties) a purchaser is to assume. This is a natural consequence of caveat emptor and the notion that ownership of property entails risk and responsibility.

Several solutions have been adopted to deal with this type of indemnity, but they are usually superficial. The vendor might impose a survival period on the indemnity equivalent to the survival period on representations and warranties. This may limit the period of exposure but certainly does not reconcile the broad scope of the indemnity with the narrower scope of the representations and warranties. Some agreements provide that the indemnity is capped at the purchase price, or has a "deductible" threshold. This is of little comfort to a vendor who believes that he should be responsible for only those specific matters for which he gave representations and warranties.

\section{B. THE VENDOR'S NEED FOR INDEMNIFICATION}

It can be argued that the vendor, on the other hand, does need a certain degree of ongoing indemnification after closing. This is because the assumption of liabilities by the purchaser is not complete at closing. Novation agreements novating the purchaser into the various ongoing agreements may take anywhere from a few days to several months to be fully executed by all third parties to such agreements. During that time, the vendor is still contractually liable for his obligations and liabilities under such agreements and it is reasonable for the purchaser to indemnify the vendor for the obligations and liabilities that accrue under those contracts after the effective time. Indeed, novation may be denied and the vendor may never be released from his obligations under the contract.

There is also the matter of governmental licenses. If the ERCB refuses to consent to a transfer of a well license to the purchaser, for example, or the legislation is amended such that any predecessor licensee is not relieved of his licensee obligations if the transferee fails to do so, ${ }^{118}$ then clearly the vendor should be indemnified for

116. Hadley v. Baxendale (1854), 156 E.R. 145.

117. Victoria Laundry (Windsor) Ld. v. Newman Industries Ld., [1949] 2 K.B. 528 (C.A.).

118. Supra, note 98. 
such matters. It is quite often provided in purchase and sale agreements that the vendor, until novation, will act as the purchaser's agent in performing, and enforcing rights under, operating and other agreements. Otherwise the purchaser could not exercise important rights such as notices of independent operations, votes and rights of first refusal. The vendor receives in return typical agent-type indemnification for this ongoing liability.

\section{DIFFERENT APPROACHES TO INDEMNIFICATION}

The practice in many American purchase and sale agreements of oil and gas properties is markedly different from the broad indemnity described above. Several different approaches are used. For example, the indemnity provision is sometimes used in an attempt to precisely define the measure and remoteness of damages that are recoverable from a breach of representations and warranties and other covenants that may be in the agreement. A typical clause reads as follows:

Vendor agrees to indemnify and save harmless Purchaser from and against any loss, damage or expense

(including reasonable solicitor/client fees) sustained by Purchaser as a direct consequence of the in-

accuracy or breach of any of the representations, warranties or covenants made by Vendor in this agreement.

In this example, it can be seen that the indemnification makes no attempt to create a separate or broader set of liabilities but, rather, seeks to define the scope of damages recoverable by the purchaser to direct losses incurred, and only for a defined set of specific breaches. It also dies with the representations and warranties, except to the extent that covenants are ongoing. This provision has a relatively clear meaning and does not need to be reconciled with the representations and warranties.

A variation of the provision is to make it apply notwithstanding that the purchaser, in his due diligence, may have determined a representation and warranty is not true. Vendor's must be careful of these types of provisions because closing could be followed by a statement of claim for a breach of a representation and warranty which the vendor genuinely thought was true, but upon which the purchaser did not rely because he knew otherwise. The only remedy of the purchaser under other provisions, properly drafted, would be to not close, as opposed to laying in the weeds and suing the vendor after closing for the breach of the representation and warranty about which the vendor was unaware. It is prudent for any vendor to expressly provide for the exclusion of any representation and warranty on which the purchaser does not rely because he obtains, before closing, knowledge damning the provision.

Another approach in American agreements is to have the property related representations and warranties terminate at closing, at which time a broad indemnity, like that first discussed above, kicks in for a term certain. This is at the other end of the spectrum from the approach above. The conceptual basis for this approach is as follows. The representations and warranties about the organization and authorization of the vendor assures the purchaser that he has an enforceable agreement with which to proceed in his due diligence. The representations and warranties concerning the properties set a standard which the purchaser verifies in his due diligence, and these representations must be true for the purchaser to be obliged to close. These latter representations and warranties do not survive closing, but are replaced by the broad indemnity limited by a survival period making the vendor liable for everything accruing prior to closing. This is simply a means of avoiding inconsistent provisions dealing with ongoing liabilities, and it reconciles the broad indemnity with representations and warranties. Quite often such indemnities will expressly exclude title matters. 
Indemnities are a much more appropriate risk allocation mechanism than representations and warranties, largely because of the reliance problems associated with representations and warranties. Indemnities operate irrespective of the indemnified party's knowledge. They are particularly useful where no amount of inquiry by either the vendor or the purchaser can confirm a state of facts. The problem of Crown royalty reassessments is an example of where a specific indemnity is useful. The purchaser's inquiries may raise doubt as to whether or not Crown royalties have been properly paid, therefore condemning reliance on the applicable representation and warranty. A specific indemnity on the matter can overcome the reliance issue.

\section{INTERCEPTING PRODUCTION REVENUE}

A statement made earlier in this paper was to the effect that conveying title to the assets being purchased is only one element of the transaction, and that it is the ongoing and uninterrupted receipt of the production revenue that is paramount. Simply conveying title to the assets and not putting the purchaser in a position to obtain his revenue would be a very serious failing on the part of purchaser's counsel.

\section{A. CONSIDERATIONS IN INTERCEPTING PRODUCTION REVENUE}

Since deregulation, production revenue has been invariably derived through the contractual sale of petroleum substances. Revenue may accrue from other sources as well, such as royalties, processing revenues by virtue of owning an interest in a gas plant or a well battery, revenues derived from the sale of geological or seismic data, revenues in excess of expenses to which an operator is entitled under an operating agreement and revenues derived from the salvage of equipment. The various sources of revenue from property and the related contracts must be identified prior to closing. The most important of these is usually production revenue by virtue of oil or gas purchase contracts.

The ideal circumstance is for the buyer of production, quite often an oil marketer or pipeline company, to recognize the purchaser of the assets through an assignment and novation agreement, fully executed and delivered at closing. This almost never happens. Oil sales contracts are usually terminable on thirty days notice and instead of novation, the buyer under the oil purchase contract simply enters into a new contract with the asset purchaser. Gas purchase contracts are for varying terms and usually the buyer under those contracts, due to his familiarity with all of their intricacies and history, insists on preparing the novation agreement. This may not happen for some time after closing. Novation agreements, because they require steps to be taken and obligations to be incurred by the buyer of production under the relevant production purchase contracts and may take months to complete because of the number of third parties, are insufficient mechanisms to effectively intercept production revenue.

One of the most effective techniques for intercepting production revenue is for the purchaser to take an absolute assignment from the vendor of the proceeds under the relevant revenue producing contract, and then to serve this on the appropriate debtor, usually the buyer under that production purchase contract. This is essentially the vendor assigning a receivable or a legal chose in action, which is a personal right of property and can be enforced or claimed by way of action. The Judicature Act ${ }^{19}$

119. R.S.A. 1980, c. J-1, s. 21. 
codified to some extent the common law dealing with assignments of debts. If the assignment meets the requirement of section 21 , the assignee will be able to bring an action in his own name for the recovery of the debt, without any input from the assignor, and give a discharge of the debt to the debtor.

Mere assignment of a chose in action does not, however, establish priority. The case of Dearle v. Hall ${ }^{120}$ established that competing assignments take priority as between each other from the date of service of such notices on the debtor. Notice to the debtor prevents the debtor from paying the assignor and obtaining a valid discharge of the debt. If he pays the assignor, the law provides that he can be made to pay again to the assignee. There is some question as to whether future debts, such as those that will arise upon future production, fall within the Judicature Act. There is a school of thought that notwithstanding the right to payment has not yet matured, a sum growing due under contract in existence at the time of the execution of the assignment is a present debt at law. ${ }^{121}$

Priority is established by the first to give notice of the assignment. ${ }^{122}$ This means that a prospective purchaser of producing assets should ensure that the debts for which he seeks assignment have not been previously assigned. There is at present no mechanism to register specific assignments of debts and therefore the purchaser must obtain his priority comfort through representations and warranties in the purchase and sale agreement and his own due diligence of the vendor's records. The purchaser must be cognizant of the statutory charges, discussed above, which can attach to personal property such as a production sales contract, without notice. The vendor may well have specifically assigned his production sales contracts to a lender who will not discharge such assignments without being repaid. Purchaser's counsel must also be aware that any assignment of a debt is subject to the equities that exist or arise between the vendor and production buyer before notice of the assignment is served. This could include the right of set-off of liquidated debts, such as those that might be owing to an operator by a non-operator.

The registration situation will change to a certain degree once the PPSA ${ }^{123}$ comes into force on October 1, 1990. That Act provides that all transfers or assignments of accounts must be registered to establish priority. ${ }^{124}$ Exceptions arise however, such as in the case of the sale of a business. ${ }^{125}$ A purchaser buying all or substantially all of the assets of a vendor does not require registration of debt assignment to establish priority.

Section 4(e) of the PPSA may also exclude from its application assignments of production sale contracts on their outright sale, because a purchaser assumes the obligations thereunder of the vendor. This is not entirely clear from a reading of the section, but if so, section 66 of the PPSA provides that the common law is not altered except to the extent inconsistent with the Act. This probably means that a prospective purchaser cannot rely solely on the PPSA for his due diligence in terms of searching

120. (1828), 38 E.R. 475.

121. R.M. Goode, Legal Problems of Credit and Security, 2nd ed. (London: Sweet \& Maxwell, 1988) Chapter IV.

122. Supra, note 120.

123. Supra, note 41.

124. Ibid., s. 3(2).

125. Ibid., s. 4(h). 
out prior sales or assignments of the contract (such as where the vendor has sold, or has committed to sell, the production purchase contract) nor in establishing his own priority when taking assignments of gas purchase contracts.

The transitional provisions of the PPSA provide that until October 1, 1993, the prior security interest has the status of a perfected security interest without filing a registration under the PPSA. After that point in time, it becomes unperfected unless it is otherwise perfected under the Act. ${ }^{126}$ This means that until October 1, 1993, a search under the PPSA will not disclose all prior debt assignments by a vendor to which a purchaser will be subject. Representations and warranties, and due diligence outside of the contract and the PPSA, will still be required until that time, and afterwards if there is concern that a previous assignment excluded from registration under section 4(e) and 4(h) could have occurred.

Registration under the PPSA will only perfect the security and establish priority. Service of assignment on the debtor is still required to intercept production revenue. This should obviously be done in a timely manner after closing if any delay in obtaining the appropriate novation agreement is expected. Identifying the correct debtor requires a review of the vendor's records. In most gas purchase contracts where there is more than one seller, one party is appointed agent for seller to receive all revenues on behalf of all sellers and distribute them to each seller. This is the person who is usually served with the notice of the assignment, but the relationship between the vendor and the agent for seller may not be one of debtor/creditor, and therefore service of the assignment on seller's agent likely does not oblige the agent to pay the proceeds to the purchaser. If the agent for seller continues to pay the vendor in this circumstance, he cannot be made to pay twice as though he were a debtor with notice, unless he separately promises to pay the purchaser. ${ }^{127}$ Purchasers must consider obtaining this promise from agent for seller. If the agent for seller does not or is expected not to respond appropriately, the gas buyer is also served. Since the gas buyer usually does not know the amount of the proceeds allocable to the different vendors under the production purchase contract, he may simply interplead the funds into court. This risk usually results in cooperation from the agent for seller.

Other debtors might be operators under operating agreements who sell the production on behalf of the vendor because the vendor does not take in kind, operators of revenue producing gas plants or facilities, or a recognized person in an operating agreement who holds the interest of the vendor in the producing assets in trust. These persons are similarly served, but again, the relationship of such persons to the vendor may not always be one of debtor/creditor. If the relationship is one of trustee/ beneficiary, and no elements of a debtor/creditor relationship exist, an absolute assignment will not have any legal effect on the trustee. Where there are no legal mechanisms of compelling the holders of production funds, such as trustees, to pay the purchaser, purchaser's counsel may want to ensure that the conditions precedent require appropriate recognition by the buyers of production of the purchaser before closing.

A further precaution purchasers should take is to provide in the purchase and sale agreement that any production revenue received by the vendor which is derived from production occurring after the effective time are trust funds and must be forwarded

126. Ibid., s. 75(5).

127. See Powell, "The Law of Agency," 2nd ed. at 276. 
forthwith to the purchaser. This at least should succeed in the trust characterization of such revenue if it is not obvious to a court. There are also other steps that can be taken, such as ensuring that closing adjustments take into account revenue which the purchaser will not be able to immediately intercept, or requiring the vendor to act as the purchaser's agent until novation and begin taking production in kind upon closing.

\section{B. PROBLEMS IN OBTAINING RECOGNITION BY TCPL}

Eventually a purchaser of assets will want to be novated into production sales contracts so that he can have control over their conduct directly with the buyer. Gas purchase contracts with Canada's largest gas purchaser, TransCanada PipeLines Limited ("TCPL") and its agent Western Gas Marketing Limited ("WGML"), into which a purchaser seeks novation, raise a number of concerns about which a purchaser must be careful. TCPL and most of the producers under its 2,400 gas purchase contracts entered into amending agreements in 1982 and 1983, (the "Topgas Agreements') to deal with take or pay gas problems. ${ }^{128} \mathrm{~A}$ very troublesome provision exists in Clause 20 of these Topgas Agreements and reads as follows:

If insufficient gas is deliverable under a particular Seller's Gas Purchase Contract to permit recovery of all Prepaid Gas under the particular Contract prior to November 1, 1994 and recovery of all TransCanada Prepaid Gas under the particular Contract then until such Prepaid Gas and such TransCanada Prepaid Gas have been recovered in full, all deliveries of Seller's gas in any month under all other gas purchase contracts to which Seller and TransCanada are parties, after the recovery of Prepaid Gas for such month under such other gas purchase contracts for the then current contract year pursuant to paragraph 11, shall constitute recovery of Prepaid Gas and thereafter shall constitute recovery of TransCanada Prepaid Gas under the particular Contract. . . .

"Prepaid Gas" and "TransCanada Prepaid Gas" is gas for which TCPL has paid but has not taken. All novation agreements into TCPL contracts invariably include novation into the Topgas Agreements if the vendor or his predecessor was a signatory to them.

The provisions of Clause 20 usually arise where the gas reserves remaining in lands dedicated to a particular TCPL contract are insufficient to permit TCPL to recover its take or pay gas, being the gas for which it has already paid under a particular contract ("deficient contract"). TCPL then has the right, on behalf of Topgas Holdings Limited and Topgas Two Inc. to go to other TCPL contracts with that vendor and take all gas from that contract to meet the deficiency under the deficient contract. This creates four important issues for a prospective purchaser of assets which include TCPL contracts.

First, TCPL will be reluctant to recognize a prospective purchaser where to do so would eliminate TCPL's rights under Clause 20 . The vendor may have two contracts, one of which is deficient, or potentially deficient, and the other, which has adequate dedicated reserves, is to be sold to the purchaser. Upon novation, TCPL will be unable to "cross dedicate" the good contract to the deficient one because the vendor is no longer a party to both. Although TCPL contracts provide that consent to assignment may not be unreasonably withheld, it certainly appears reasonable for TCPL's consent to be withheld where to do so would prejudice its rights under Clause 20 of the Topgas Agreements. Prior to obliging itself to purchase the assets, the purchaser should satisfy himself that he can obtain the recognition of TCPL. Otherwise, the 
purchaser will find himself the owner of producing assets without being recognized as the seller under the relevant gas purchase contract, facing the possibility that his revenues under the gas purchase contract may disappear to meet a deficiency under the asset vendor's other TCPL contracts.

Second, the purchaser must also consider the obverse situation where he already owns a deficient contract and no other TCPL contracts which are cross dedicated to it by Clause 20 . He may not want to purchase a non-deficient TCPL contract only to see its revenues disappear to satisfy his existing deficient contract.

Third, the purchaser may presently own non-deficient TCPL contracts and part of the assets he intends to buy may include a deficient TCPL contract, or a potentially deficient one. The deficient one he buys may not, in the hands of the vendor, permit TCPL to cross dedicate its deficiency to a good contract because the vendor may not have any other TCPL contracts. TCPL would naturally be delighted if a purchaser with a non-deficient TCPL contract buys a deficient or potentially deficient one, thereby upgrading TCPL's security position in respect of Clause 20 . The purchaser may then see his non-deficient contract unnecessarily "bled" by the deficient one he bought.

Fourth, the situation is further complicated where the vendor or purchaser is named as a seller in TCPL contracts which also have other sellers named in the same contracts. These contracts describe all of the sellers as "Seller", and a reading of the contract makes it fairly certain that each seller in such contract is jointly liable for all the obligations of Seller under the contract. How is Clause 20 of the Topgas Agreements applied in these circumstances? TCPL apparently takes the position that where $A$ and $B$ are sellers in Contract No. 1, and A is the sole party in Contract No. 2 with TCPL, a deficiency in Contract No. 1 can be made up in its entirety from A's single seller Contract No. 2. The obverse is not similarly treated, however. In the above example, if A's Contract No. 2 is deficient, TCPL apparently takes the position that it can draw the deficiency from A's share only of Contract No. 1. TPCL's rationale is likely that the Topgas Agreements, which were entered into with one seller at a time and not jointly, define Prepaid Gas and TransCanada Prepaid Gas on a contract by contract basis, and not in terms of seller's portion, and it is therefore the full amount of such gas in Contract No. 1 that seller is cross dedicating to his other Contract No. 2. Since A and not B, in Contract No. 2, cross dedicated only that contract's "Prepaid Gas" and "TransCanada Prepaid Gas" under Clause 20, only A's gas in Contract No. 1 should be exigible.

The reality of the foregoing to a purchaser is that he must carefully consider the effects of Clause 20 of the Topgas Agreements because if he fails to do so he can seriously impair his existing or acquired assets. There is a further twist to the foregoing maze. Many sellers in TCPL gas purchase contracts have silent parties standing behind them who are not named in the contract. In those instances there seems to be little doubt that the named seller is liable under a Clause 20 cross dedication for the full amount of the deficiency under such a contract to his other TCPL contracts, not just his beneficial portion of the deficient contract. A prospective purchaser should be very alert to this circumstance, particularly where a vendor is attempting to "unload" a deficient contract.

It is fortunate that WGML is normally very co-operative with prospective purchasers' inquires into the status of TCPL contracts. Obtaining the written consent of the vendor for WGML to disclose the contractual relationship is usually all that is required. This process is essential where any TCPL contract is at issue. It is also prudent for purchaser's counsel to provide the necessary protections in the purchase 
and sale agreement where TCPL contracts are to be acquired. This protection will usually be in the form of a condition precedent which will describe the circumstances that must be met in respect of TCPL contracts before the purchaser will close.

\section{EFFECTIVE DATES}

Many purchase and sale agreements provide that the effective time of the sale is a time of a day preceding the closing date by several days or even months. Notwithstanding that the purchaser is not actually conveying the property until the closing, the agreement often reads that the purchaser is entitled to the fruits of the properties as though he owned them commencing the effective time. This raises a number of concerns. The vendor owns the property until it is conveyed, and designating a prior effective time cannot change that. The vendor is therefore theoretically liable for income taxes exigible from revenues arising from to the property between the effective time and the closing date. The purchaser will not normally compensate the vendor for such tax. Similarly, the vendor is theoretically entitled to ARTC in respect of royalties paid on production from the property between the effective time and the closing date, simply because he is the owner of the property until closing. Apparently, Revenue Canada and Alberta Treasury permit some latitude in having an effective time precede a closing, and it is generally considered that the maximum permissible period of a time is one month. This is because of the recognition that it is difficult in the oil and gas industry to cut accounts off mid-month. If the period is longer, the purchaser and vendor can expect problems from Revenue Canada and Alberta Treasury, particularly where the vendor is taxable and the purchaser is not.

Purchasers and vendors can avoid the problem simply by having the effective time correspond or at least be adequately proximate to the closing date and making the appropriate adjustments to the purchase price. This usually involves adjusting on the basis of net revenue between the effective time and closing, with interest applicable to the previously contemplated effective time purchase price up to closing.

\section{CONCLUSION}

Counsel for vendors and purchasers of producing oil and gas properties must be astutely aware of the minefield of legal pitfalls through which his client must tread. The number of problems that can arise in purchases of producing properties is unlimited, and this paper discusses but a few of them. Helping the purchaser understand the ramifications of caveat emptor and the vendor the nature and meaning of ongoing liabilities, while fostering respect for each other's concerns, can reduce the tension between the vendor's and purchaser's divergent goals and facilitiate their attainment. 